\title{
Animal allergens and their presence in the environment
}

\section{Eva Zahradnik and Monika Raulf*}

Institute for Prevention and Occupational Medicine of the German Social Accident Insurance, Institute of the Ruhr-Universität Bochum (IPA), Bochum, Germany

\section{Edited by:}

Christiane Hilger, Centre de

Recherche Public Santé, Luxembourg

\section{Reviewed by:}

Mark A. Suckow, University of Notre Dame, USA

Inge M. Wouters, Institute for Risk

Assessment Sciences, Netherlands

\section{*Correspondence:}

Monika Raulf, Center of

Allergology/Immunology, Institute for

Prevention and Occupational

Medicine of the German Social

Accident Insurance, Institute of the

Ruhr-Universität Bochum (IPA),

Bürkle-de-la-Camp-Platz 1, 44789

Bochum, Germany

e-mail: raulf@ipa-dguv.de
Exposure to animal allergens is a major risk factor for sensitization and allergic diseases. Besides mites and cockroaches, the most important animal allergens are derived from mammals. Cat and dog allergies affect the general population; whereas, allergies to rodents or cattle is an occupational problem. Exposure to animal allergens is not limited to direct contact to animals. Based on their aerodynamic properties, mammalian allergens easily become airborne, attach to clothing and hair, and can be spread from one environment to another. For example, the major cat allergen Fel $d 1$ was frequently found in homes without pets and in public buildings, including schools, day-care centers, and hospitals. Allergen concentrations in a particular environment showed high variability depending on numerous factors. Assessment of allergen exposure levels is a stepwise process that involves dust collection, allergen quantification, and data analysis. Whereas a number of different dust sampling strategies are used, ELISA assays have prevailed in the last years as the standard technique for quantification of allergen concentrations. This review focuses on allergens arising from domestic, farm, and laboratory animals and describes the ubiquity of mammalian allergens in the human environment. It includes an overview of exposure assessment studies carried out in different indoor settings (homes, schools, workplaces) using numerous sampling and analytical methods and summarizes significant factors influencing exposure levels. However, methodological differences among studies have contributed to the variability of the findings and make comparisons between studies difficult. Therefore, a general standardization of methods is needed and recommended.

\section{INTRODUCTION}

Exposure to animal allergens is a major risk factor for the development of sensitization and allergic diseases such as asthma, allergic rhinitis/conjunctivitis, and atopic dermatitis $(1,2)$. Generally, intensive contact with any animal, including diverse arthropods, reptiles, birds, and mammals, can induce allergic reactions $(3,4)$. Apart from ubiquitous mites and cockroaches, the most frequent allergies developed are those to domesticated mammals with fur that are typically kept as pets or farm animals $(1,5)$. Contact with animals arises via many different occupations and activities. Cats, dogs, guinea pigs, hamsters, and rabbits are all very popular pets in industrialized countries, where the percentage of pet ownership continues to increase (6). Horses, whose use has decreased in agriculture, are today widely owned for recreational riding and show activities. Besides pigs, cows are the most common farm animals used for dairy and meat production. Another important source of occupational animal allergies is the handling of laboratory animals (7). Rodents, especially mice and rats, are kept in large numbers in research facilities of universities and pharmaceutical industries. In addition to these rodents housed in laboratories or occasionally kept as pets, mice, and rats can infest human urban and agricultural environments, where they find food supplies and have few predators.

During the past few decades, the distribution of various mammalian allergens has been extensively studied. Based on this research, it can be stated that animal allergens are present ubiquitously in the human environment, even though concentrations differ considerably. Numerous studies of animal allergen exposure levels in different locations and geographical regions have been published, with variable results that have been attributed to the use of different study designs (e.g., kind and number of samples, exposure grouping, data analysis). A mandatory requirement to assess allergen exposure is the availability of a reliable assay for allergen quantification. Therefore, this article focuses on well-characterized mammalian allergens derived from cats, dogs, mice, rats, cows, and horses for which very sensitive and specific ELISA assays have been validated. Some of these assays are currently commercially available (Indoor Biotechnologies, Charlottesville, VA, USA). Although, several allergens from other mammals (e.g., rabbit, guinea pig, ferret, hamster, chinchilla) have also been identified [summarized by Díaz-Perales et al. (6)], no assays for these species have been developed or published so far.

As a background, a short overview of characteristics of major allergens and sensitization rates in different population groups are presented in this report. The main focus of this review is a summary of exposure assessment studies conducted in recent years. Reported allergen levels and relevant factors associated with concentration differences are described for different exposure settings. Examples of studies were selected based on the fact that they were carried out in different environments (homes, workplaces, public 
buildings) using various dust sampling methods. Recommendations with regard to standardization of methods are being made for future research.

\section{COMMON FEATURES OF ANIMAL ALLERGENS INFLUENCING THEIR UBIQUITY}

Inhalant allergens derived from mammals comprise a large and complex group. With the exception of the cat allergen Fel d 1, the majority of all animal major allergens belong to the lipocalin protein family (8). Typically, lipocalins from mammals are small extracellular proteins composed of approximately 150-170 amino acids with a molecular mass of about $20 \mathrm{kDa}$. Lipocalins share common biological functions that are predominantly related to the transport of small hydrophobic molecules such as steroids, odorants, and pheromones. Although, the overall amino acid identity between lipocalins is low (usually between 20 and 30\%), this protein family is characterized by conserved sequence motifs and a common tertiary structure. Albumins represent another large protein family containing several respiratory allergens. They are components of serum and regulate osmotic pressure of blood. Compared to lipocalins, albumins are of minor allergic importance, but they are often responsible for allergic cross-reactions between animal dander of different species due to the high sequence identity among family members (about 80\%) (9, 10). A partial cross-reactivity also exists between several lipocalins; however, the clinical relevance of this feature needs to be assessed (11).

Animal allergens are mainly produced in the liver or secretory glands and localized in animal skin and body fluids, such as urine, saliva, blood, milk, and sweat. These proteins adhere to fur and other surfaces. The allergens can be efficiently dispersed into the environment as animals shed hair and dander, and secrete and excrete fluids. Indoors, the allergens accumulate primarily in different textiles, including carpets, upholstery, mattresses, and curtains where they are detectable for a long time, even after removal of the animal (12-14). In addition, the aerodynamic properties of animal allergens influence their environmental distribution and human exposure. Especially, lipocalins tend to be carried on a diverse range of small dust particles, from $<1$ to $20 \mu \mathrm{m}$. Some proportion of allergens $(<5 \mu \mathrm{m})$ can stay suspended in the air for extended periods of time (15). In contrast, mite allergens are primarily associated with large-sized $(>20 \mu \mathrm{m})$ dust particles that settle rapidly (16). Based on their aerodynamic characteristics, animal allergens can be transferred to environments that were never occupied by the animals, such as public buildings, including schools, day-care centers, hospitals, and offices (17). Although, the concentrations of the allergens are low in these environments, they may be high enough to cause symptoms in sensitized individuals $(18,19)$.

There is strong evidence that clothing is the primary transfer mechanism of allergens. Significantly higher allergen levels have been found in dust collected from pet owners' clothes than from the clothes of non-pet owners (20,21). Furthermore, allergen levels have been shown to be dependent on clothing type and washing frequency (22). Egmar et al. (23) studied the accumulation of animal allergens in furniture stores by comparing the dust from factory-new mattresses to used ones. Allergen concentration correlated to the period of time that the mattresses were used by customers. In addition to clothing, human hair is also an important vehicle for transfer, and thus a source of animal allergens $(24,25)$.

\section{MEASUREMENT OF ALLERGEN EXPOSURE}

Measuring airborne allergens is necessary to detect allergen sources, to assess the relationship between allergen exposure, sensitization, and symptoms and to generate preventive measures. Allergen exposure assessment comprises two essential procedures: collection of dust samples and quantification of allergen levels. For both steps, a large variety of sampling strategies and analytical tests are available. However, the different methods used have made it difficult to compare the results among the different studies. Although, a general standardization would be preferred, in practice the variations cannot be avoided. The choice of sampling method is often influenced by the size of the study, available budget, practical performance, aerodynamics of the relevant allergens, and relevance to the personal exposure. Each method has advantages and disadvantages depending on the aims and technical limitations of the investigation (26).

\section{DUST SAMPLING}

Reservoir or settled dust sampling by vacuuming of surfaces is the most common method used for determining domestic exposure, e.g., pet allergens at home. It is inexpensive, easy, and fast to perform and therefore, widely applied in large-scale studies. Dust is collected on filters or in nylon bags mounted in special sampling devices that are commercially available (27). Several surfaces can be vacuumed, including floors (smooth or carpeted), beds (mattress or bedding), and furniture (sofas, chairs, desks). Apart from the collector and surface type, differences occur in the power of vacuum cleaner, size of the area sampled, sampling time, and sampling location (living room, bedroom, or kitchen). Collected dust may be sieved by some researchers to separate coarse particles. All the variations described influence the amount and composition of dust, and ultimately the results of the allergen analysis. Results are expressed as allergen per unit weight or per square meter, and although significant relationships have been shown between allergen levels in reservoir dust and allergic diseases, the relevance to personal exposure is still questionable. Many collected dust particles never become airborne and are therefore never inhaled.

Airborne dust sampling using pumps is commonly used in occupational settings, for example to measure mouse allergens in laboratories. According to the aerodynamic properties of animal allergens, airborne levels might be more suitable for defining exposure to pets. This method requires time, expensive equipment, and trained staff. The pumps are noisy and need recharging and calibration. Dust is sampled using several types of filters and sampling heads constructed for collection of particles with defined size (e.g., inhalable, respirable dust). Air may be sampled stationary by low $(2-20 \mathrm{~L} / \mathrm{min})$ or high volume $(60-1100 \mathrm{~L} / \mathrm{min})$ pumps, or using person-carried pumps often at flow rates of 2 or $3.5 \mathrm{~L} / \mathrm{min}$. Different sample volumes and collection times directly affect the lower detection limits, and dust amounts are strongly dependent on activities in the room causing air disturbance. Results are expressed as allergen per cubic meter of air. In comparison to reservoir dust, 
airborne dust may be considered a more representative measure of inhaled allergen. Personal sampling in the breathing zone used for task and shift measurements is regarded as a gold standard in occupational settings.

Another method that can be used to collect airborne dust is the ion-charging device (28). This technique is based on a commercial air cleaner, where particles in the air are loaded with a positive charge, which allows them to attract and bind to the negatively charged collector plates. In general, airborne measurements are rarely performed in home environments because of high logistic costs.

Settling or passive airborne dust sampling is an alternative or a complement to the other two sampling techniques. This method collects airborne dust that has settled over a period of time (e.g., 2 weeks) on a certain sampling height (e.g., $1.5 \mathrm{~m}$ above the floor). In recent years, several sampling devices have been used such as Petri dishes (29), aluminum foil-covered boxes (30), or electrostatic cloths (31). Results are expressed in allergen per square meter (and per day). Settling dust seems to correlate moderately with both airborne dust as well as reservoir dust. Due to its low cost, ease of use, and simple transport, this method is suitable for large-scale exposure studies.

\section{ALLERGEN ANALYSIS}

Standard methods for allergen quantification are immunoassays based on specific antibodies directed against the allergens. A broad panel of assays has been developed (32), but some methods such as quantitative immunelectrophoresis or ELISA inhibition are hardly used. In the past two decades, ELISAs (enzyme linked immunosorbent assay) in "sandwich" design have been established as the gold standard for allergen analysis (33). The antibodies may be either monoclonal or polyclonal against either allergen mixtures or single allergens. Variations occur according to the source, specificity and purity of antibodies. In particular, the choice of standard (e.g., animal dander extract or purified or recombinant major allergens) and its protein determination method (Bradford-, BCA-, Lowryassay, amino acid analysis) may influence the resulting values up to several orders of magnitude. Furthermore, several detection (conjugates) and visualization (substrates) methods are available.

The increasing interest and need to quantify allergens in different environments in recent years has led to the development of multiplex arrays for indoor allergens (MARIA) (34). Multiplex technology uses the same (or equivalent) antibody combinations used in ELISAs. Capture antibodies are covalently coupled to polystyrene beads that are internally labeled with fluorophores. Combining different bead types with different antibodies allows simultaneous measurement of several allergens in a single test.

\section{CATS AND DOGS}

The popularity of cats and dogs as pets means that allergy to both animals affects the general population. In Europe, the frequency of pet ownership is highly variable. Cat ownership ranged from 7.2 to $35 \%$ (average 14.9\%) and dog ownership from 5.4 to 35\% (average $12 \%$ ) across 12 European birth cohorts with a total of 25,056 subjects (35). In the United States, according to the American Pet Products Manufacturers Association, nearly 40 and 33\% of households own dogs and cats, respectively (36). Equally, the prevalence of sensitization also varies in different countries because of cultural differences and environmental factors. A large patient-based study GA ${ }^{2}$ LEN (The Global Asthma and Allergy European Network) investigated the sensitization patterns for diverse inhalant indoor and outdoor allergens across 14 European countries using skin prick testing (5). The overall European sensitization frequency to cats and dogs were very similar, but regional differences were found. Cat sensitization rate was $26.3 \%$, ranging from 16.8 to $49.3 \%$. The rate of sensitization to dog allergens was $27.2 \%$, ranging from 16.1 to $56 \%$. Sensitization rates to both allergens were particularly high in Nordic countries (e.g., Denmark and Finland) and lower in Central/Western and Mediterranean countries (e.g., Austria, Belgium, Italy). In the US Inner City Asthma Study, skin test sensitivity among asthmatic children was $41 \%$ to cat allergens and $21 \%$ to dog allergens (37). Naturally, in the general population, the sensitization frequencies are much lower compared with those detected in patient populations (5). In a recent survey, performed in Germany (38), 7\% of 7025 adult participants were sensitized to cat as well as to dog allergens (detection of specific IgE). Allergy to pets may also occur in some professions where workers are heavily exposed to animal dander during most of their working time. Work-related allergic symptoms have been reported in animal laboratory workers (30\% to cats, $25 \%$ to dogs) and veterinarians $(26 \%$ to cats, $19 \%$ to dogs) when handling animals $(39,40)$. However, it has to be considered that these persons may also handle animals before and/or outside of their respective careers.

\section{CAT (FELIS DOMESTICUS)}

Cat dander contains several allergens. The major cat allergen Fel $\mathrm{d} 1$ is the most extensively studied animal allergen with regard to its structure, aerodynamic properties, environmental distribution, and the relationship between allergen exposure and the development of allergic disease $(41,42)$. Fel d 1 is a tetrameric glycoprotein formed by two heterodimers and has an apparent molecular weight of about $38 \mathrm{kDa}$ (43). It reacts with IgE from over $90 \%$ of cat-sensitized individuals (44). In contrast to other animal major allergens, Fel d 1 is not a lipocalin. The three dimensional structure of Fel d 1 is very similar to that of uteroglobins, antiinflammatory proteins, but its biological function is still unknown (45). Fel d 1 is primarily found in cat skin and hair follicles and is produced in sebaceous, anal, and salivary glands (46-48). It is transferred to the fur by licking and grooming. Male cats produce a larger amount of Fel d 1 than female cats (49). Fel d 1 was mainly associated with particles $>9 \mu \mathrm{m}$, representing approximately $49 \%$ of the total allergen recovered. About $23 \%$ of airborne Fel d 1 was carried on small particles $<4.7 \mu \mathrm{m}$ (12). Other cat allergens are: Fel d $2(67 \mathrm{kDa})$, serum albumin; Fel d $3(11 \mathrm{kDa})$, cystatin; the second major cat allergen Fel d $4(20 \mathrm{kDa})$, lipocalin; Fel d 5, immunoglobulin A; Fel d 6, immunoglobulin M; Fel d 7 (18 kDa), von Ebner gland protein; and Fel d $8(24 \mathrm{kDa})$, latherin $(11,50)$.

\section{DOG (CANIS FAMILIARIS)}

Hair/dander and saliva are the main sources of dog allergens. The major dog allergen, Can f 1 (about $22-24 \mathrm{kDa}$ ) belongs to the lipocalin family of proteins and is produced in tongue epithelial tissue (51). About, 70\% of dog allergic subjects have been shown to have IgE directed to Can $\mathrm{f} 1(51,52)$. Similar to Fel d 1 in cats, 
males produce more Can $\mathrm{f} 1$ than females (53). The particle size distribution of Can $\mathrm{f} 1$ is similar to that of Fel d 1 as well (54). Although, differences in Can $\mathrm{f} 1$ allergen production have been found between different dog breeds, the variability between individuals is very large and a hypoallergenic breed does not exist (53, 55). Further dog allergens are: Can f 2 (24-27 kDa), lipocalin; Can f $3(67 \mathrm{kDa})$, serum albumin; Can f $4(16 \mathrm{kDa})$, lipocalin; Can f 5 $(28 \mathrm{kDa})$, prostatic kallikrein; and Can f $6(27-29 \mathrm{kDa})$, lipocalin $(11,50)$.

\section{PET EXPOSURES}

There are an overwhelming number of publications concerning the quantitative measurements of cat and dog allergens. Studies have been conducted worldwide but the research has been most active in the United States and in European countries. Study results are presented in Table $\mathbf{1}$ for cat allergens and in Table $\mathbf{2}$ for dog allergens. Most of the investigations chosen have estimated the levels of both cat and dog allergens in parallel. A further common feature of these studies is the usage of the same (or very similar) quantification method. The sandwich ELISA for cat allergens is based on two monoclonal antibodies, 6F9 and 3E4 against Fel d 1 (56). The sandwich ELISA for dog allergens is a combination of a monoclonal capture antibody 6E9 and polyclonal detection antibody against Can $\mathrm{f} 1$ (57). Both assays are commercially available by Indoor Biotechnologies. Currently, Fel d 1 and Can f 1 can also be quantified with the multiplex array MARIA (Indoor Biotechnologies). In this system, the original Can $\mathrm{f} 1$ ELISA was modified to use two monoclonal antibodies, 10D4 for capture and biotinylated 6E9 for detection. Commercial Fel d 1 and Can f 1 assays use purified natural single allergens as the standard quantified by amino acid analysis, but variations can occur in the protein standard used, which is not always specified in the relevant publications.

The most important finding of all studies is that cat and dog allergens are ubiquitously found in every type of human indoor environment, regardless of the presence of pets, most likely due to passive transfer via clothing. Exposure levels vary widely between different environments and geographical regions. For example, a multicenter cross-sectional study measured Fel d 1 levels in mattress dust from 2800 households in 22 municipal areas across Europe (61). European regions showed substantial differences with respect to allergen levels, with the highest concentrations of Fel $\mathrm{d}$ 1 found in central European countries followed by the northern and finally southern countries. The overall geometric mean was $0.94 \mu \mathrm{g} / \mathrm{g}$, ranging from the lowest measured value of $0.12 \mu \mathrm{g} / \mathrm{g}$ in Huelva, Spain to the highest of $3.76 \mu \mathrm{g} / \mathrm{g}$ in Antwerp, Belgium. The major strength of this study was the good comparability among different regions because the identical dust collection protocol was used, and Fel d 1 measurements were performed in one single laboratory using identical batches of ELISA kits.

Apart from the high variability, exposure intensity/degree is primarily related to the presence (past or present) of a pet in the home. Not surprisingly, cat and dog allergen concentrations were found to be much higher in homes with pets than in homes without pets, as shown using both reservoir dust samples $(58,60-62$, $64,73)$ and air samples $(58,59)$. In settled dust, there was an 80 - to 250-fold difference for Fel d 1, and 25- to 120-fold difference for
Can $\mathrm{f} 1$ between houses with and without pets. Higher geometric mean of cat allergens has been also estimated in homes where cats were once present compared with those that never housed cats (61). Homes with outdoor dogs had significantly higher dog allergen levels than homes without any dogs, but significantly lower levels than homes with indoor dogs (73). Another multicenter cross-sectional survey from the United States investigated the distribution of Can $\mathrm{f} 1$ and Fel d 1 within households according to the sampling site and vacuumed surface (60). Independent of the presence of pets, the highest concentrations of both allergens were found in living room sofas. In homes with pets, such high concentrations generally indicated the favorite indoor location of the animals; whereas, in homes without pets, such sites were those that came into most contact with clothing. Additionally, sofas are generally less frequently cleaned than floors or bedding.

Different infrastructural characteristics (urban, suburban, rural) also appear to influence the allergen exposure intensity. Suburban homes contained higher levels of cat and dog allergens than inner city homes, probably reflecting the higher rate of pet ownership in these households (62). In rural homes, the median concentrations of cat and dog allergens in mattresses were significantly lower than in those from urban houses, probably reflecting the different habits of pet owners (75). In rural areas, animals are usually kept outdoors, whereas more indoors pets are found in cities. Moreover, a study from Norway has reported that genderspecific differences can occur in pet allergen exposure among children (63). Girls had higher concentrations of cat and dog allergens in their mattresses compared with boys, also after adjustment for pet ownership. This was most likely caused by differences in behavior, such as a greater affinity among girls to cuddle pets or the tendency to decorate their rooms with soft toys, which may act as reservoirs for allergens.

To explore the differences in allergen distribution among different dog breeds, allergen levels in settled airborne dust (electrostatic cloths) were measured in homes of various so-called hypoallergenic (Labradoodle, Poodle, Spanish Waterdog, Airedale terrier) and non-hypoallergenic dogs (Labrador retriever, control heterogeneous group). Despite Can $\mathrm{f} 1$ differences in hair samples between hypoallergenic and non-hypoallergenic dogs (with enormous variability between individual dogs of the same breed), no differences were observed in environmental levels. Surprisingly, airborne Can $\mathrm{f} 1$ concentrations in homes were similar across different breeds and no evidence was found for a reduced production of allergen by hypoallergenic dogs (55).

Besides domestic settings, many studies on indoor allergens have focused on schools and day-care centers due to lengthy periods that children spend in these locations. A comparison of settled dust samples between these two types of environments suggests that cat and dog allergen levels in schools are higher than in homes where no pets are present $(64,68)$. These results clearly demonstrate that educational facilities may be the most important site of persistent exposure for some children and thus a risk factor, especially for those who are allergic or asthmatic. Higher allergen concentrations were found in furniture compared to floors $(64,66)$, consistent with what was described above for personal home environments. Furthermore, carpeted floors contained higher allergen levels than smooth floors $(65,66)$. Fel $d 1$ and Can $\mathrm{f} 1$ were 
Table 1 | Studies related to exposure assessment to cat allergen.

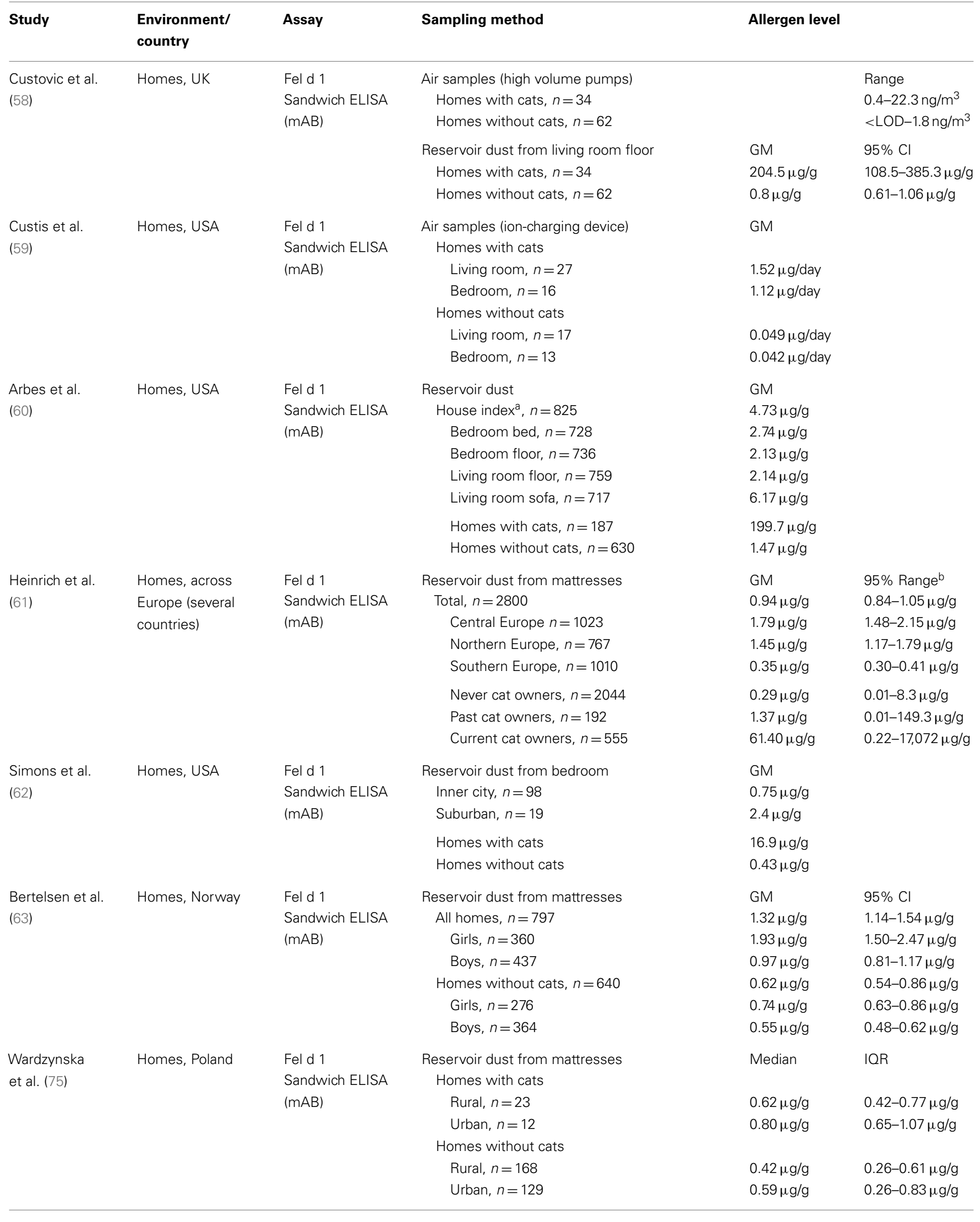


Table 1 | Continued

\begin{tabular}{|c|c|c|c|c|c|}
\hline Study & $\begin{array}{l}\text { Environment/ } \\
\text { country }\end{array}$ & Assay & Sampling method & Allergen level & \\
\hline \multirow{6}{*}{$\begin{array}{l}\text { Perzanowski } \\
\text { et al. (64) }\end{array}$} & \multirow{6}{*}{$\begin{array}{l}\text { Schools and } \\
\text { homes, Sweden }\end{array}$} & \multirow{6}{*}{$\begin{array}{l}\text { Fel d } 1 \\
\text { Sandwich ELISA } \\
(\mathrm{mAB})\end{array}$} & Reservoir dust & GM & Range \\
\hline & & & Schools, $n=176$ & $0.76 \mu \mathrm{g} / \mathrm{g}$ & $<\mathrm{LOD}-13 \mu \mathrm{g} / \mathrm{g}$ \\
\hline & & & Desk and chairs, $n=64$ & $2.6 \mu \mathrm{g} / \mathrm{g}$ & $<\mathrm{LOD}-13 \mu \mathrm{g} / \mathrm{g}$ \\
\hline & & & Floors, $n=64$ & $0.31 \mu \mathrm{g} / \mathrm{g}$ & $<\mathrm{LOD}-8.8 \mu \mathrm{g} / \mathrm{g}$ \\
\hline & & & Homes without cats, $n=74$ & $0.42 \mu \mathrm{g} / \mathrm{g}$ & $<\mathrm{LOD}-9.4 \mu \mathrm{g} / \mathrm{g}$ \\
\hline & & & Homes with cats, $n=9$ & $33 \mu \mathrm{g} / \mathrm{g}$ & $1.8-950 \mu \mathrm{g} / \mathrm{g}$ \\
\hline \multirow{6}{*}{$\begin{array}{l}\text { Karlsson et al. } \\
\text { (29) }\end{array}$} & \multirow[t]{6}{*}{ Schools, Sweden } & \multirow{6}{*}{$\begin{array}{l}\text { Fel d } 1 \\
\text { Sandwich ELISA } \\
(\mathrm{mAB})\end{array}$} & Petri dishes (5 days) & Median & \\
\hline & & & Many cat owners in class, $n=22$ & $81.0 \mathrm{ng} / \mathrm{m}^{2} /$ day & \\
\hline & & & Few cat owners in class, $n=22$ & $14.2 \mathrm{ng} / \mathrm{m}^{2} /$ day & \\
\hline & & & Air personal samples (pumps) & & \\
\hline & & & Many cat owners in class, $n=22$ & $1.6 \mathrm{ng} / \mathrm{m}^{3}$ & \\
\hline & & & Few cat owners in class, $n=22$ & $0.3 \mathrm{ng} / \mathrm{m}^{3}$ & \\
\hline \multirow{5}{*}{$\begin{array}{l}\text { Arbes et al. } \\
\text { (65) }\end{array}$} & \multirow{5}{*}{$\begin{array}{l}\text { Day-care centers, } \\
\text { USA }\end{array}$} & \multirow{5}{*}{$\begin{array}{l}\text { Fel d } 1 \\
\text { Sandwich ELISA } \\
(\mathrm{mAB})\end{array}$} & Reservoir dust from floors & $\mathrm{GM}$ & \\
\hline & & & 89 Day-care centers & $1.43 \mu \mathrm{g} / \mathrm{g}$ & \\
\hline & & & 20 Day-care centers & & \\
\hline & & & Carpet & $2.28 \mu \mathrm{g} / \mathrm{g}$ & \\
\hline & & & Smooth floor & $0.39 \mu \mathrm{g} / \mathrm{g}$ & \\
\hline \multirow[t]{6}{*}{$\begin{array}{l}\text { Tranter et al. } \\
\text { (66) }\end{array}$} & \multirow{6}{*}{$\begin{array}{l}\text { Schools and } \\
\text { day-care centers, } \\
\text { USA }\end{array}$} & \multirow{6}{*}{$\begin{array}{l}\text { Fel d } 1 \\
\text { Sandwich ELISA } \\
(\mathrm{mAB})\end{array}$} & $\begin{array}{l}\text { Reservoir dust from floors } \\
\text { Schools }\end{array}$ & Median & IQR \\
\hline & & & Carpet, $n=79$ & $0.28 \mu \mathrm{g} / \mathrm{m}^{2}$ & $0.14-0.77 \mu \mathrm{g} / \mathrm{m}^{2}$ \\
\hline & & & Tile, $n=65$ & $0.014 \mu \mathrm{g} / \mathrm{m}^{2}$ & $0.006-0.027 \mu \mathrm{g} / \mathrm{m}^{2}$ \\
\hline & & & Day-care centers & & \\
\hline & & & Carpet, $n=42$ & $0.42 \mu \mathrm{g} / \mathrm{m}^{2}$ & $0.14-0.9 \mu \mathrm{g} / \mathrm{m}^{2}$ \\
\hline & & & Furniture, $n=18$ & $1.6 \mu \mathrm{g} / \mathrm{m}^{2}$ & $0.74-4.0 \mu \mathrm{g} / \mathrm{m}^{2}$ \\
\hline \multirow[t]{2}{*}{ Cai et al. (67) } & \multirow{2}{*}{$\begin{array}{l}\text { Day-care centers, } \\
\text { Sweden }\end{array}$} & Fel d 1 & Petri dishes (30-40 days) & GM & Range \\
\hline & & $\begin{array}{l}\text { Sandwich ELISA } \\
(\mathrm{mAB})\end{array}$ & Diverse rooms, $n=97$ & $9.4 \mathrm{ng} / \mathrm{m}^{2} /$ day & $0.9-78.6 \mathrm{ng} / \mathrm{m}^{2} /$ day \\
\hline \multirow{5}{*}{$\begin{array}{l}\text { Permaul et al. } \\
\text { (68) }\end{array}$} & \multirow{5}{*}{$\begin{array}{l}\text { Schools and } \\
\text { homes, USA }\end{array}$} & Fel d 1 & Reservoir dust & GM & Range \\
\hline & & MARIA & Schools, $n=229$ & $0.19 \mu \mathrm{g} / \mathrm{g}$ & $0.004-285.8 \mu \mathrm{g} / \mathrm{g}$ \\
\hline & & \multirow[t]{3}{*}{$(\mathrm{mAB})$} & Homes (bedroom), $n=118$ & $0.06 \mu \mathrm{g} / \mathrm{g}$ & $0.004-392.3 \mu \mathrm{g} / \mathrm{g}$ \\
\hline & & & Air samples (ion-charging device) & & \\
\hline & & & Schools, $n=196$ & $1.82 \mathrm{ng} / \mathrm{m}^{3}$ & \\
\hline \multirow{3}{*}{$\begin{array}{l}\text { Custovic et al. } \\
\text { (69) }\end{array}$} & \multirow[t]{3}{*}{ Hospitals, UK } & Fel d 1 & Reservoir dust from upholstered & GM & Range \\
\hline & & Sandwich ELISA & chairs, $n=42$ & $22.9 \mu \mathrm{g} / \mathrm{g}$ & $4.5-58 \mu \mathrm{g} / \mathrm{g}$ \\
\hline & & $(\mathrm{mAB})$ & Air samples (high volume pumps) & & $<\mathrm{LOD}-0.22 \mathrm{ng} / \mathrm{m}^{3}$ \\
\hline \multirow{3}{*}{$\begin{array}{l}\text { Partti-Pellinen } \\
\text { et al. (70) }\end{array}$} & \multirow{3}{*}{$\begin{array}{l}\text { Public transport } \\
\text { vehicles, Finland }\end{array}$} & Fel d 1 & Reservoir dust & Median & Range \\
\hline & & Sandwich ELISA & Seats, $n=8$ & $0.87 \mu \mathrm{g} / \mathrm{g}$ & $0.003-2.6 \mu \mathrm{g} / \mathrm{g}$ \\
\hline & & $(\mathrm{mAB})$ & Floors, $n=10$ & $0.01 \mu \mathrm{g} / \mathrm{g}$ & $0.002-0.08 \mu \mathrm{g} / \mathrm{g}$ \\
\hline \multirow{2}{*}{$\begin{array}{l}\text { Macher et al. } \\
\text { (71) }\end{array}$} & \multirow[t]{2}{*}{ Offices, USA } & Fel d 1 & Reservoir dust from floors & Median & Range \\
\hline & & $\begin{array}{l}\text { Sandwich ELISA } \\
(\mathrm{mAB})\end{array}$ & 92 offices, $n=251$ & $0.3 \mu \mathrm{g} / \mathrm{g}$ & $<\mathrm{LOD}-19 \mu \mathrm{g} / \mathrm{g}$ \\
\hline \multirow{4}{*}{$\begin{array}{l}\text { Samadi et al. } \\
(72)\end{array}$} & \multirow{4}{*}{$\begin{array}{l}\text { Animal hospital, } \\
\text { Netherlands }\end{array}$} & Fel d 1 & Different locations & GM & Range \\
\hline & & Sandwich & Air personal samples (pumps), $n=67$ & $0.3 \mathrm{ng} / \mathrm{m}^{3}$ & $<\mathrm{LOD}-9.4 \mathrm{ng} / \mathrm{m}^{3}$ \\
\hline & & $E L I S A+M A R I A$ & Electrostatic cloths ( 14 days), $n=30$ & $56 \mathrm{ng} / \mathrm{m}^{2}$ & $<\mathrm{LOD}-579 \mathrm{ng} / \mathrm{m}^{2}$ \\
\hline & & $(m A B)$ & Reservoir dust from floors, $n=110$ & $11 \mathrm{ng} / \mathrm{m}^{2}$ & $0.2-183 \mathrm{ng} / \mathrm{m}^{2}$ \\
\hline
\end{tabular}

mAB, monoclonal antibodies; GM, geometric mean; IQR, interquartile range; $\mathrm{Cl}$, confidence interval; LOD, limit of detection.

${ }^{a}$ House index represents the mean of the sample location concentrations.

${ }^{b} 95 \%$ Range calculated as log mean plus and minus two standard deviations and back-transformed. 
Table 2 | Studies related to exposure assessment to dog allergen.

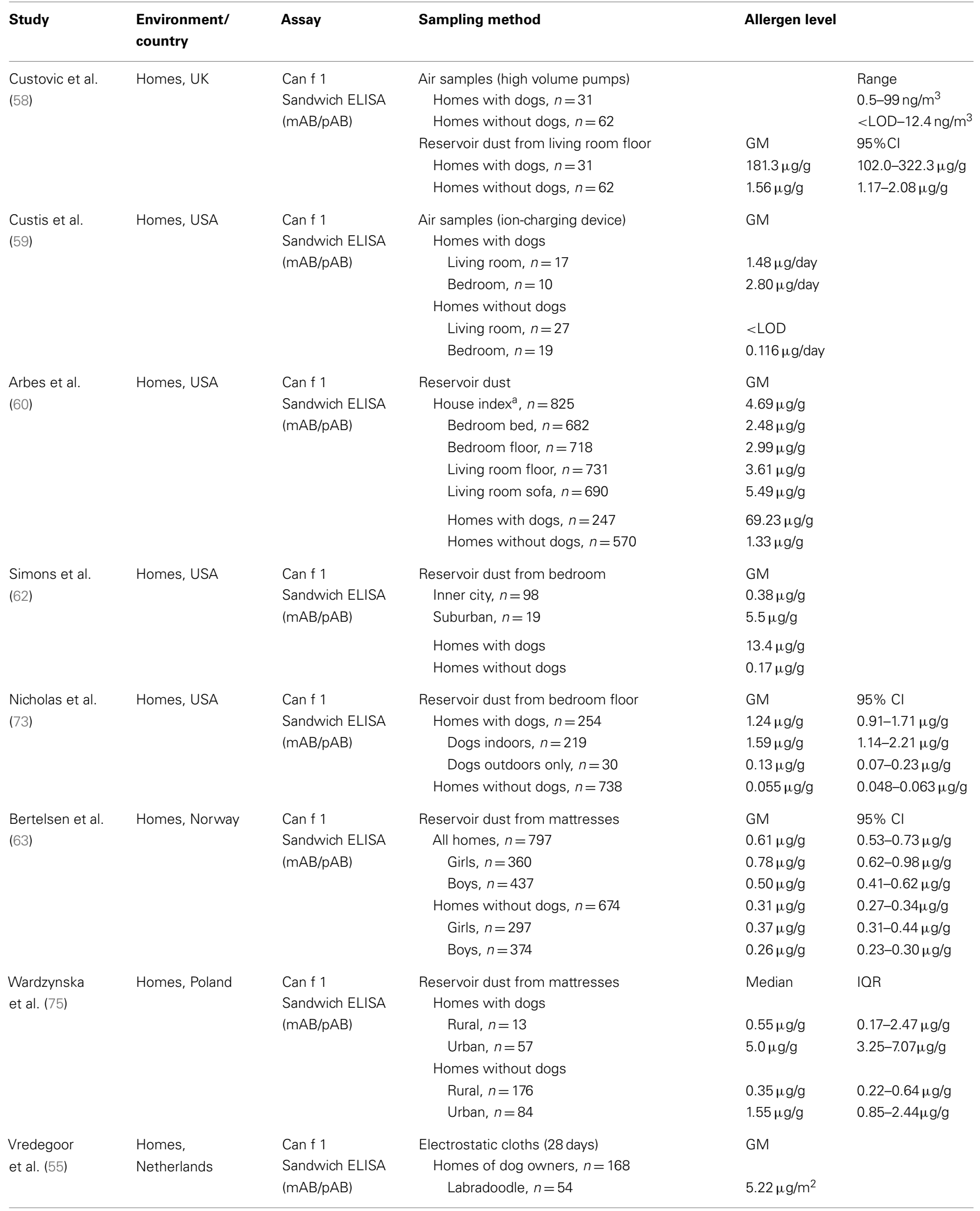


Table 2 | Continued

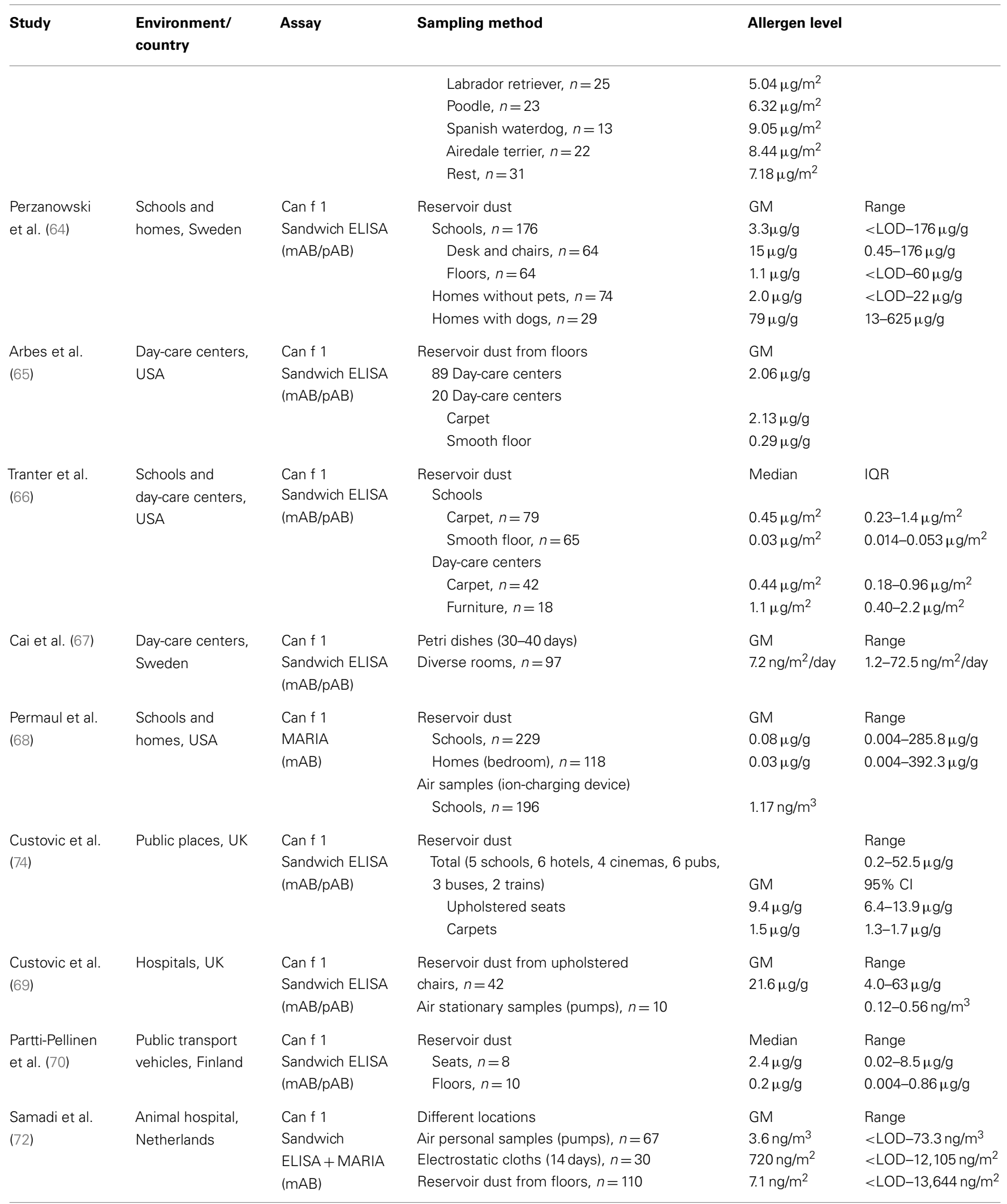

$m A B$, monoclonal antibodies; $P A B$, polyclonal antibodies; GM, geometric mean; IQR, interquartile range; $C l$, confidence interval; $L O D$, limit of detection.

${ }^{a}$ House index represents the mean of the sample location concentrations. 
also detectable in active airborne dust (ion-charging device) from schools (68) and passive airborne dust (Petri dishes) from daycare centers (67). Karlsson et al. (29) have shown that airborne Fel $d 1$ concentrations in schools were strongly dependent on the number of children with cats at home. Median cat allergen levels in both Petri dishes and personal air samples were approximately fivefold higher in classes with many cat owners $(>20 \%)$ compared to classes with few cat owners $(<10 \%)$.

The widespread distribution of cat and dog allergens is further demonstrated by several studies carried out in other public indoor environments. Fel $\mathrm{d} 1$ and Can $\mathrm{f} 1$ have been measured in reservoir dust from seats and floors inside public buildings such as hotels, cinemas and pubs (74), hospitals (69), office buildings (71), and in public transport vehicles such as buses, trams, and trains $(70,74)$. In general, seats were more contaminated with pet allergens compared to floors, presumably because they come in direct contact with clothing.

Reports on measuring exposure to pet allergens in occupational settings are rare. One study investigated the allergen levels in veterinary medicine students, and workers in a companion animal hospital using various dust collection methods throughout different locations (72). In personal airborne samples, significant differences in exposure levels were found for Fel $\mathrm{d} 1$ and Can $\mathrm{f}$ 1 between the different performed tasks. The highest exposure was observed in the intensive care unit and during practical animal courses for students. Allergen concentrations varied greatly between different locations, with the highest levels measured in the examination and waiting rooms (reservoir dust) and in the intensive care unit (electrostatic cloths) and the lowest in the operating room (both methods). Exposure levels in dust captured by diverse sampling methods only correlated moderately with each other.

\section{RODENTS}

Allergy to mice and rats is an important occupational health problem, primarily because these animals are the most widely used in medical research. Rodent allergy is commonly observed among technicians, animal caretakers, physicians, and scientists who work in pharmaceutical industries, university laboratories, and animal breeding facilities. In occupational settings, the prevalence rates of rodent allergies vary from 11 to $44 \%$ depending on the diagnostic methods (questionnaire or laboratory testing) used (76). The prevalence of mouse and rat allergy is very similar. In a large cross-sectional survey from Japan that included over 5000 laboratory animal workers, $26 \%$ reported allergic symptoms to mice and $25 \%$ to rats (39). Sensitization and work-related symptoms occur at the latest, 2-3 years after the initial exposure to laboratory animals (77). Besides an atopic background, the most important risk factor for the development of an allergy to rodents is the level of exposure to laboratory animal allergens. Children of parents who are occupationally exposed to laboratory animals were shown to have more frequently positive skin prick tests against mice, rats, and hamsters compared to children of non-exposed parents (78). Studies from the United States have demonstrated that rodent allergen exposure in domestic environments is also clinically relevant. In inner city children with asthma, the prevalence of mouse sensitization (skin test sensitivity) ranged from 11 to $46 \%$ (79), and the prevalence of rat sensitization was estimated to be $21 \%$
(80). A recent study from Europe has reported a very low sensitization prevalence ( $1.6 \%$ for mouse and $0.6 \%$ for rat) in urban atopic populations without occupational exposure (81).

\section{MOUSE (MUS MUSCULUS)}

Rodent allergens can be found in dander, hair, urine, saliva, and serum. Urine is the main source of allergenic proteins in both mice and rats. The major mouse allergen, Mus $\mathrm{m} 1$ (about $19 \mathrm{kDa}$ ) is a prealbumin and lipocalin-odorant binding protein (82) belonging to the rodent family of major urinary proteins (MUP) (83). MUPs are produced in the liver and other exocrine glands under hormonal control. Mouse MUPs are encoded by 35 genes, with 15 forms detectable in urine. The expression of MUPs varies according to species, strains, sexes, and individuals. MUPs seem to play a complex role in chemosensory signaling among rodents. Study of particle size distribution revealed that airborne Mus $\mathrm{m}$ 1 is carried on particles with aerodynamic diameter ranging from 0.4 to $>10 \mu \mathrm{m}$, with the majority on particles between 3.3 and $10 \mu \mathrm{m}(84)$.

To quantify mouse allergens, sandwich ELISAs were developed by several groups using polyclonal antibodies produced in rabbit or sheep (84-86). In these studies, either the purified Mus $\mathrm{m} 1$ or the whole protein from mouse urine was used as the immunogen or standard. Therefore, some assays are known in the literature as mouse urinary allergen (MUA) or MUP. A polyclonal antibodybased assay is commercially available as the Mus $\mathrm{m} 1$ ELISA kit or as a component of the MARIA (Indoor Biotechnologies).

Numerous studies of mouse allergen exposure levels were conducted in occupational settings such as laboratory animal facilities of universities, research institutes, and pharmaceutical companies (Table 3). Ohman et al. (84) demonstrated that Mus $\mathrm{m} 1$ is widely distributed in the air of a major mouse breeding facility, even in rooms that do not house mice (e.g., offices). This was shown for stationary as well as for personal air samples. Direct contact to mice was associated with the highest Mus $\mathrm{m} 1$ levels (up to $560 \mathrm{ng} / \mathrm{m}^{3}$ ). Within mouse rooms, airborne Mus $\mathrm{m} 1$ levels were strongly correlated with the number of mice in the room. Another large-scale study (seven different facilities) investigated the personal allergen exposure intensity according to the type of job and the type of tasks performed (85). Animal technicians and caretakers had elevated median MUA exposure levels compared with the scientific staff and supervisors. Removal of contaminated bedding from cages and moving animals into new cages were associated with the highest personal exposure; lower exposures were seen with feeding or handling the animals. However, mouse allergen concentrations during tasks varied enormously among different facilities ( $<$ LOD-2000 $\mathrm{ng} / \mathrm{m}^{3}$ ), probably due to the differences in cleaning practices and feeding technologies, or the local ventilation equipment.

A recent study from the Jackson Laboratory assessed mouse allergen exposure across a range of jobs, including non-mouse handlers (87). Although mouse handlers had significantly higher median levels of mouse allergen than non-handlers (4.13 vs. $\left.0.21 \mathrm{ng} / \mathrm{m}^{3}\right), 71 \%$ of administrative/support personnel and $68 \%$ of materials/supplies handlers had detectable mouse allergen levels, in some cases in concentrations similar to those measured in animal caretakers. Among mouse handlers, those involved 
Table 3 | Studies related to exposure assessment to mouse allergen.

\begin{tabular}{|c|c|c|c|c|c|}
\hline Study & $\begin{array}{l}\text { Environment/ } \\
\text { country }\end{array}$ & Assay & Sampling method & Allergen level & \\
\hline $\begin{array}{l}\text { Ohman et al. } \\
\text { (84) }\end{array}$ & $\begin{array}{l}\text { Mouse facility, } \\
\text { USA }\end{array}$ & $\begin{array}{l}\text { Mus m } 1 \\
\text { Sandwich ELISA } \\
\text { (pAB) }\end{array}$ & $\begin{array}{l}\text { Air samples } \\
\text { Stationary } \\
\text { Mouse rooms } \\
\text { Offices and lunch room } \\
\text { Personal } \\
\text { Mouse rooms } \\
\text { Offices and lunch room }\end{array}$ & $\begin{array}{l}\text { Range of } \mathrm{AM} \\
0.5-15.1 \mathrm{ng} / \mathrm{m}^{3} \\
0.2-1.5 \mathrm{ng} / \mathrm{m}^{3} \\
16.6-563 \mathrm{ng} / \mathrm{m}^{3} \\
1.2-2.7 \mathrm{ng} / \mathrm{m}^{3}\end{array}$ & \\
\hline $\begin{array}{l}\text { Hollander et al. } \\
\text { (85) }\end{array}$ & $\begin{array}{l}\text { Laboratory animal } \\
\text { facilities, } \\
\text { Netherlands }\end{array}$ & $\begin{array}{l}\text { MUA } \\
\text { Sandwich ELISA } \\
(\mathrm{pAB})\end{array}$ & $\begin{array}{l}\text { Air samples (personal) } \\
\text { Job categories, } n=171 \\
\text { Animal caretaker, } n=63 \\
\text { Animal technicians, } n=94 \\
\text { Scientists, } n=2 \\
\text { Supervisor, } n=12 \\
\text { Task categories, } n=123 \\
\text { Cage emptying, } n=25 \\
\text { Changing animals, } n=33 \\
\text { Feeding animals, } n=19 \\
\text { Handling animals, } n=8 \\
\text { Experiments, } n=2 \\
\text { Biotechnical work, } n=11 \\
\text { Cage wash, } n=8 \\
\text { Cleaning rooms, } n=17\end{array}$ & $\begin{array}{l}\text { Median } \\
12.1 \mathrm{ng} / \mathrm{m}^{3} \\
6.4 \mathrm{ng} / \mathrm{m}^{3} \\
2.7 \mathrm{ng} / \mathrm{m}^{3} \\
0.58 \mathrm{ng} / \mathrm{m}^{3} \\
\mathrm{GM} \\
74.8 \mathrm{ng} / \mathrm{m}^{3} \\
22.8 \mathrm{ng} / \mathrm{m}^{3} \\
19.6 \mathrm{ng} / \mathrm{m}^{3} \\
16.0 \mathrm{ng} / \mathrm{m}^{3} \\
33.5 \mathrm{ng} / \mathrm{m}^{3} \\
5.4 \mathrm{ng} / \mathrm{m}^{3} \\
2.6 \mathrm{ng} / \mathrm{m}^{3} \\
2.1 \mathrm{ng} / \mathrm{m}^{3}\end{array}$ & 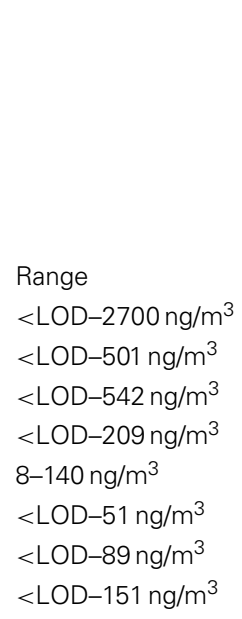 \\
\hline $\begin{array}{l}\text { Curtin-Brosnan } \\
\text { et al. (87) }\end{array}$ & $\begin{array}{l}\text { Mouse facility, } \\
\text { USA }\end{array}$ & $\begin{array}{l}\text { Mus m } 1 \\
\text { Sandwich ELISA } \\
\text { (pAB) }\end{array}$ & $\begin{array}{l}\text { Air samples (personal) } \\
\text { Mouse handlers, } n=97 \\
\text { Non-mouse handlers, } n=71 \\
\text { Job categories } \\
\text { Animal caretaker, } n=57 \\
\text { Administrative personnel, } n=34 \\
\text { Supplies/Material handler, } n=19 \\
\text { Task categories (mouse handlers) } \\
\text { Animal care, } n=42 \\
\text { Husbandry, } n=26 \\
\text { Experiments, } n=25\end{array}$ & $\begin{array}{l}\text { Median } \\
4.13 \mathrm{ng} / \mathrm{m}^{3} \\
0.21 \mathrm{ng} / \mathrm{m}^{3} \\
9.6 \mathrm{ng} / \mathrm{m}^{3} \\
0.23 \mathrm{ng} / \mathrm{m}^{3} \\
0.63 \mathrm{ng} / \mathrm{m}^{3} \\
8.73 \mathrm{ng} / \mathrm{m}^{3} \\
5.83 \mathrm{ng} / \mathrm{m}^{3} \\
0.36 \mathrm{ng} / \mathrm{m}^{3}\end{array}$ & $\begin{array}{l}\text { IOR } \\
0.70-12.12 \mathrm{ng} / \mathrm{m}^{3} \\
<\text { LOD-0.63 ng/m³ } \\
\text { Range } \\
0.58-220.9 \mathrm{ng} / \mathrm{m}^{3} \\
<\mathrm{LOD}-30.94 \mathrm{ng} / \mathrm{m}^{3} \\
<\mathrm{LOD}-423.9 \mathrm{ng} / \mathrm{m}^{3} \\
\text { IQR } \\
3.56-18.68 \mathrm{ng} / \mathrm{m}^{3} \\
3.26-14.95 \mathrm{ng} / \mathrm{m}^{3} \\
0.07-1.77 \mathrm{ng} / \mathrm{m}^{3}\end{array}$ \\
\hline $\begin{array}{l}\text { Renström } \\
\text { et al. (86) }\end{array}$ & $\begin{array}{l}\text { Laboratory animal } \\
\text { facility, Sweden }\end{array}$ & $\begin{array}{l}\text { MUA } \\
\text { Sandwich ELISA } \\
\text { (pAB) }\end{array}$ & $\begin{array}{l}\text { Air samples (stationary) } \\
\text { Open cages, } n=11 \\
\text { IVC } 1, n=13 \\
\text { IVC } 2, n=15\end{array}$ & $\begin{array}{l}\text { Median } \\
44 \mathrm{ng} / \mathrm{m}^{3} \\
0.62 \mathrm{ng} / \mathrm{m}^{3} \\
4.3 \mathrm{ng} / \mathrm{m}^{3}\end{array}$ & $\begin{array}{l}\text { IOR } \\
36-45 \mathrm{ng} / \mathrm{m}^{3} \\
<\mathrm{LOD}-2.4 \mathrm{ng} / \mathrm{m}^{3} \\
2.7-8.8 \mathrm{ng} / \mathrm{m}^{3}\end{array}$ \\
\hline $\begin{array}{l}\text { Thulin et al. } \\
\text { (88) }\end{array}$ & $\begin{array}{l}\text { Laboratory animal } \\
\text { facility, Sweden }\end{array}$ & $\begin{array}{l}\text { MUA } \\
\text { Sandwich ELISA } \\
\text { (pAB) }\end{array}$ & $\begin{array}{l}\text { Air samples (personal) } \\
\text { Cage changing } \\
\text { Unventilated table, } n=5 \\
\text { Ventilated changing wagon, } n=5 \\
\text { Handling animals } \\
\text { Outside ventilated bench, } n=9 \\
\text { Ventilated bench, } n=6\end{array}$ & $\begin{array}{l}\mathrm{GM} \\
77.3 \mathrm{ng} / \mathrm{m}^{3} \\
17.2 \mathrm{ng} / \mathrm{m}^{3} \\
\\
87.2 \mathrm{ng} / \mathrm{m}^{3} \\
2.1 \mathrm{ng} / \mathrm{m}^{3}\end{array}$ & $\begin{array}{l}\text { Range } \\
65.1-88 \mathrm{ng} / \mathrm{m}^{3} \\
14.0-20.8 \mathrm{ng} / \mathrm{m}^{3} \\
34.8-220 \mathrm{ng} / \mathrm{m}^{3} \\
0.6-9.8 \mathrm{ng} / \mathrm{m}^{3}\end{array}$ \\
\hline Krop et al. (25) & $\begin{array}{l}\text { Homes of animal } \\
\text { caretakers, } \\
\text { Netherlands }\end{array}$ & $\begin{array}{l}\text { MUA } \\
\text { Sandwich ELISA } \\
\text { (pAB) }\end{array}$ & $\begin{array}{l}\text { Reservoir dust from mattresses } \\
\text { Laboratory animal workers, } n=15 \\
\text { Controls (no contact to animals), } n=15\end{array}$ & $\begin{array}{l}\mathrm{GM} \\
29.5 \mathrm{ng} / \mathrm{g} \\
8.8 \mathrm{ng} / \mathrm{g}\end{array}$ & $\begin{array}{l}95 \% \mathrm{Cl} \\
11.7-74.6 \mathrm{ng} / \mathrm{g} \\
4.6-16.8 \mathrm{ng} / \mathrm{g}\end{array}$ \\
\hline
\end{tabular}


Table 3 | Continued

\begin{tabular}{|c|c|c|c|c|c|}
\hline Study & $\begin{array}{l}\text { Environment/ } \\
\text { country }\end{array}$ & Assay & Sampling method & Allergen level & \\
\hline $\begin{array}{l}\text { Phipatanakul } \\
\text { et al. (89) }\end{array}$ & Homes, USA & $\begin{array}{l}\text { Mus m } 1 \\
\text { Sandwich ELISA } \\
\text { (pAB) }\end{array}$ & $\begin{array}{l}\text { Reservoir dust from bed, furniture, floor } \\
\text { Bedroom, } n=506 \\
\text { Living room, } n=608 \\
\text { Kitchen, } n=559\end{array}$ & $\begin{array}{l}\text { Median } \\
0.52 \mu \mathrm{g} / \mathrm{g} \\
0.57 \mu \mathrm{g} / \mathrm{g} \\
1.60 \mu \mathrm{g} / \mathrm{g}\end{array}$ & $\begin{array}{l}\text { Range } \\
<\text { LOD-294 } \mu \mathrm{g} / \mathrm{g} \\
<\text { LOD-203 } \mu \mathrm{g} / \mathrm{g} \\
<\mathrm{LOD}-618 \mu \mathrm{g} / \mathrm{g}\end{array}$ \\
\hline $\begin{array}{l}\text { Matsui et al. } \\
\text { (90) }\end{array}$ & Homes, USA & $\begin{array}{l}\text { Mus m } 1 \\
\text { Sandwich ELISA } \\
\text { (pAB) }\end{array}$ & $\begin{array}{l}\text { Reservoir dust from bed, furniture, floor } \\
\text { Inner city } \\
\text { Bedroom, } n=78 \\
\text { Living room, } n=77 \\
\text { Kitchen, } n=75 \\
\text { Suburban } \\
\text { Bedroom, } n=257 \\
\text { Living room, } n=250 \\
\text { Kitchen, } n=250\end{array}$ & $\begin{array}{l}\text { Median } \\
0.76 \mu \mathrm{g} / \mathrm{g} \\
0.99 \mu \mathrm{g} / \mathrm{g} \\
2.48 \mu \mathrm{g} / \mathrm{g} \\
0.012 \mu \mathrm{g} / \mathrm{g} \\
0.016 \mu \mathrm{g} / \mathrm{g} \\
0.007 \mu \mathrm{g} / \mathrm{g}\end{array}$ & $\begin{array}{l}\text { IOR } \\
0.16-3.21 \mu \mathrm{g} / \mathrm{g} \\
0.18-5.59 \mu \mathrm{g} / \mathrm{g} \\
0.27-18.95 \mu \mathrm{g} / \mathrm{g} \\
<\mathrm{LOD}-0.048 \mu \mathrm{g} / \mathrm{g} \\
<\mathrm{LOD}-0.044 \mu \mathrm{g} / \mathrm{g} \\
<\mathrm{LOD}-0.050 \mu \mathrm{g} / \mathrm{g}\end{array}$ \\
\hline $\begin{array}{l}\text { Simons et al. } \\
(62)\end{array}$ & Homes, USA & $\begin{array}{l}\text { Mus m } 1 \\
\text { Sandwich ELISA } \\
(\mathrm{pAB})\end{array}$ & $\begin{array}{l}\text { Reservoir dust from beds and floors } \\
\text { Bedroom } \\
\text { Inner city, } n=98 \\
\text { Suburban, } n=19 \\
\text { Air samples } \\
\text { Bedroom } \\
\text { Inner city, } n=98 \\
\text { Suburban, } n=19\end{array}$ & $\begin{array}{l}\mathrm{GM} \\
3.2 \mu \mathrm{g} / \mathrm{g} \\
0.013 \mu \mathrm{g} / \mathrm{g} \\
\\
0.055 \mathrm{ng} / \mathrm{m}^{3} \\
0.016 \mathrm{ng} / \mathrm{m}^{3}\end{array}$ & \\
\hline $\begin{array}{l}\text { Chew et al. } \\
\text { (91) }\end{array}$ & Schools, USA & $\begin{array}{l}\text { MUP } \\
\text { Sandwich ELISA } \\
\text { (pAB) }\end{array}$ & $\begin{array}{l}\text { Reservoir dust from floors } \\
11 \text { Schools, } 87 \text { classrooms }\end{array}$ & $\begin{array}{l}\text { Range of GM } \\
0.21-133 \mu \mathrm{g} / \mathrm{g}\end{array}$ & $\begin{array}{l}\text { Range of samples } \\
<\text { LOD-1125 } \mu \mathrm{g} / \mathrm{g}\end{array}$ \\
\hline $\begin{array}{l}\text { Arbes et al. } \\
\text { (65) }\end{array}$ & $\begin{array}{l}\text { Day-care centers, } \\
\text { USA }\end{array}$ & $\begin{array}{l}\text { Mus m } 1 \\
\text { Sandwich ELISA } \\
(\mathrm{pAB})\end{array}$ & $\begin{array}{l}\text { Reservoir dust from floors } \\
89 \text { Day-care centers } \\
20 \text { Day-care centers } \\
\text { Carpet } \\
\text { Smooth floor }\end{array}$ & $\begin{array}{l}\mathrm{GM} \\
0.01 \mu \mathrm{g} / \mathrm{g} \\
0.008 \mu \mathrm{g} / \mathrm{g} \\
0.004 \mu \mathrm{g} / \mathrm{g}\end{array}$ & \\
\hline $\begin{array}{l}\text { Sheehan et al. } \\
\text { (92) }\end{array}$ & $\begin{array}{l}\text { Schools and } \\
\text { homes, USA }\end{array}$ & $\begin{array}{l}\text { MUP } \\
\text { Sandwich ELISA } \\
(p A B)\end{array}$ & $\begin{array}{l}\text { Reservoir dust } \\
\text { Schools (floor, desks, chairs), } n=46 \\
\text { Homes (bedroom), } n=38\end{array}$ & $\begin{array}{l}\mathrm{GM} \\
1.66 \mu \mathrm{g} / \mathrm{g} \\
0.41 \mu \mathrm{g} / \mathrm{g}\end{array}$ & $\begin{array}{l}\text { Range } \\
<\text { LOD-238 } \mu \mathrm{g} / \mathrm{g} \\
<\mathrm{LOD}-6.97 \mu \mathrm{g} / \mathrm{g}\end{array}$ \\
\hline $\begin{array}{l}\text { Permaul et al. } \\
\text { (68) }\end{array}$ & $\begin{array}{l}\text { Schools and } \\
\text { homes, USA }\end{array}$ & $\begin{array}{l}\text { Mus m } 1 \\
\text { MARIA } \\
(\mathrm{pAB})\end{array}$ & $\begin{array}{l}\text { Reservoir dust } \\
\text { Schools (floor, desks, chairs), } n=229 \\
\text { Homes (bedroom), } n=118 \\
\text { Air samples } \\
\quad \text { Schools, } n=196\end{array}$ & $\begin{array}{l}\text { GM } \\
0.65 \mu \mathrm{g} / \mathrm{g} \\
0.10 \mu \mathrm{g} / \mathrm{g} \\
1.80 \mathrm{ng} / \mathrm{m}^{3}\end{array}$ & $\begin{array}{l}\text { Range } \\
0.001-544.4 \mu \mathrm{g} / \mathrm{g} \\
0.002-82.6 \mu \mathrm{g} / \mathrm{g}\end{array}$ \\
\hline
\end{tabular}

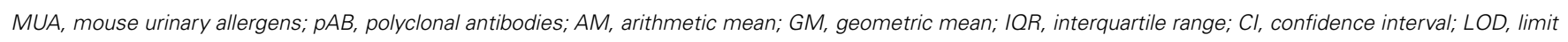
of detection.

in animal care or husbandry had higher allergen levels than those conducting laboratory experiments. Several studies examined the effects of caging systems and various ventilation and automation measures in reducing allergen levels. For example, in undisturbed animal rooms mouse allergen levels were much lower using individually ventilated cage (IVC) system compared to open cages (86). Using a ventilated cage changing wagon or handling animals on ventilated benches also resulted in lower exposure levels (88). Krop et al. (25) investigated the spreading of laboratory animal allergens outside the animal facilities. The authors found that levels of rodent allergens were significantly higher in mattress dust of laboratory animal workers compared with those of unexposed controls. In addition, high amounts of mouse allergens were recovered from hair-covering cups (not routinely used by laboratory animal workers), and therefore the authors concluded that the transfer of allergens via uncovered hair was the most likely cause for the spread of these allergens to the home. 
In the past decade, the importance of rodent allergens outside of the workplace has been demonstrated in several studies (Table 3 ). Mouse allergen seems to be widespread in US communities and may be regarded as an environmental allergen. Phipatanakul et al. (89) analyzed house dust samples (bedroom, living room, and kitchen) from 608 homes of major inner city areas (New York, Baltimore, Chicago, Cleveland, Detroit, St Louis, Washington). Ninety-five percent of all homes had detectable Mus $\mathrm{m} 1$ in at least one room, with the highest levels found in kitchens. Matsui et al. (90) compared the distribution of mouse allergen between inner city and suburban homes (surroundings of Baltimore). The prevalence of Mus $\mathrm{m} 1$ was lower in suburban homes (e.g., bedrooms: 69 vs. $94 \%$ ) and at approximately 100-fold lower concentrations (e.g., living room: 0.99 vs. $0.016 \mu \mathrm{g} / \mathrm{g}$ ), compared with homes in the inner city. These differences were confirmed by another study based in Baltimore that analyzed both air samples and settled dust from bedrooms (62). The inner city homes also had significantly higher airborne mouse allergen levels than suburban homes, reflecting the higher rate of reported mouse infestation ( 80 vs. $5 \%$ ) in cities.

Quantification of mouse allergen was also performed in school and day-care settings. Mouse allergen was detectable in $81 \%$ of settled dust samples collected from 11 schools in a major metropolitan area in the northeastern USA (91). Mouse allergen levels varied greatly between schools with geometric means (GM) ranging from 0.21 to $133 \mu \mathrm{g} / \mathrm{g}$. In contrast, very low Mus m 1 (GM: $0.01 \mu \mathrm{g} / \mathrm{g}$ ) concentrations were found in 86 day-care facilities in North Carolina, with a prevalence of $83 \%$ of all samples collected (65). The aim of two other studies was to investigate allergen exposure in schools compared with homes $(68,92)$. Both studies reported significantly higher levels of mouse allergen in classrooms vs. students' bedrooms (settled dust samples). Mus $\mathrm{m} 1$ was also detectable in airborne samples from schools using a very sensitive MARIA multiplex array. Airborne and settled dust Mus $\mathrm{m} 1$ levels in classrooms were moderately correlated $(r=0.48 ; p<0.0001)$.

\section{RAT (RATTUS NORVEGICUS)}

Analogous to mouse allergens, the major rat allergen Rat $\mathrm{n} 1$ (about $17 \mathrm{kDa}$ ) is a prealbumin or $\alpha-2 \mathrm{u}$-globulin that belongs to the lipocalin group and to the family of MUPs. The amino acid identity between mouse and rat MUPs is approximately $65 \%$ (83, 93). A major difference between species is that MUPs are glycosylated in rats but not in mice. Furthermore, the urine of male rats contains much larger quantities of Rat $\mathrm{n} 1$ than urine collected from female rats. Airborne rat allergen was detected on particles raging from $>0.5$ to $20 \mu \mathrm{m}$ with the majority on particles larger than $8 \mu \mathrm{m}$ (94).

The ELISA assays for rat allergen measurements are based on polyclonal antibodies against whole protein isolated from rat urine (85), or monoclonal antibodies against the major allergen Rat $\mathrm{n}$ $1(80,95)$. One assay based on the monoclonal antibodies RUP1 and RUP6 is commercially available by Indoor Biotechnologies as the Rat $\mathrm{n} 1$ ELISA kit or as a component of the MARIA.

As for mice, occupational exposure to rat allergens is well documented in the literature, but with fewer published studies. For many studies, exposure to rodent allergens in the workplace was assessed in parallel, with the same findings (Table 4). Briefly, rat allergen levels in laboratory animal facilities are dependent on room, job, and task $(85,96)$. More specifically, airborne Rat $n 1$ was significantly higher in rat rooms than in experimental rooms, and the highest personal exposure was measured for animal technicians and caretakers, compared with students and scientists. Cage cleaning resulted in much higher rat allergen levels than animal handling. In addition, exposure varied strongly with facility. One study assessed the individual exposure to rodent allergens using nasal air samplers and demonstrated the effectiveness of personal respiratory protection equipment (97). This unique sampling device is worn inside the nostrils and controlled by the wearer's breathing. The inhaled particles are collected by impaction on adhesive tape within the samplers. Using this method, clear differences in allergen levels ( $2.6 \mathrm{vs}$. $0.1 \mathrm{ng} / \mathrm{h}$ ) were seen between high exposure tasks (manual cage emptying, animal handling) and low exposure tasks (automated cage changing, supervision). In addition, nasal air sampling correlated well with conventional sampling using air pumps $(r=0.8)$. The study also clearly showed that the use of face masks decreased the amount of inhaled allergen by about $90 \%$. Rat allergen was also detected in dust collected from mattresses of laboratory animal workers (25).

In contrast to mice, the distribution of rat allergens outside of occupational settings is not well studied, probably due to much lower prevalence of rats indoors. Thus far, only one study has examined rat allergen exposure in the home environment (80) and reported Rat $\mathrm{n} 1$ in $33 \%$ of inner city homes (settle dust samples). This is in contrast to mouse allergen, which was detectable in $95 \%$ of the homes. Rat allergen was more common in the TV/living room $(27 \%)$ than in the kitchen (19\%) and bedroom $(21 \%)$. The median level for all rooms was below the limit of detection, and there was no correlation between rat and mouse allergens in dust samples. The authors attributed this dissimilarity to the differences in nesting habits between the both rodents. Rats do not nest in buildings, but rather build their nests in underground burrows in close proximity to water. Mice on the other hand are more likely to live indoors and nest near food stores. These territorial differences were compatible with reported rodent infestations, where $51 \%$ of families reported mice infestation, whereas only $8 \%$ reported problems with rats. Another possible explanation for the disparity between the prevalence of mouse and rat allergen levels is that the rat allergen assay was not sensitive enough to detect allergens in these samples. A second study focusing on allergen exposure in urban schools and homes assessed Rat $n 1$ concentrations in settled and airborne dust using the very sensitive MARIA technology (68). Again, no significant differences in rat allergen levels were detected in this sample set, suggesting that rat allergen exposure may occur primarily outdoors.

\section{HORSE (EQUUS CABALLUS)}

Horse allergy mainly affects people who are in direct contact to horses, either occupationally or for recreational purposes. Exposed subjects are farmers, stable-workers, breeders, veterinarians, and horse owners or riders. The prevalence of horse sensitization in occupational settings varies between 3.6 and 16.5\% (98). However, the sensitization rate in the general population is not well known. Some cases of horse allergy, despite a lack of regular exposure, have been described in children (99) and adults (100). A 
Table 4 | Studies related to exposure assessment to rat allergen.

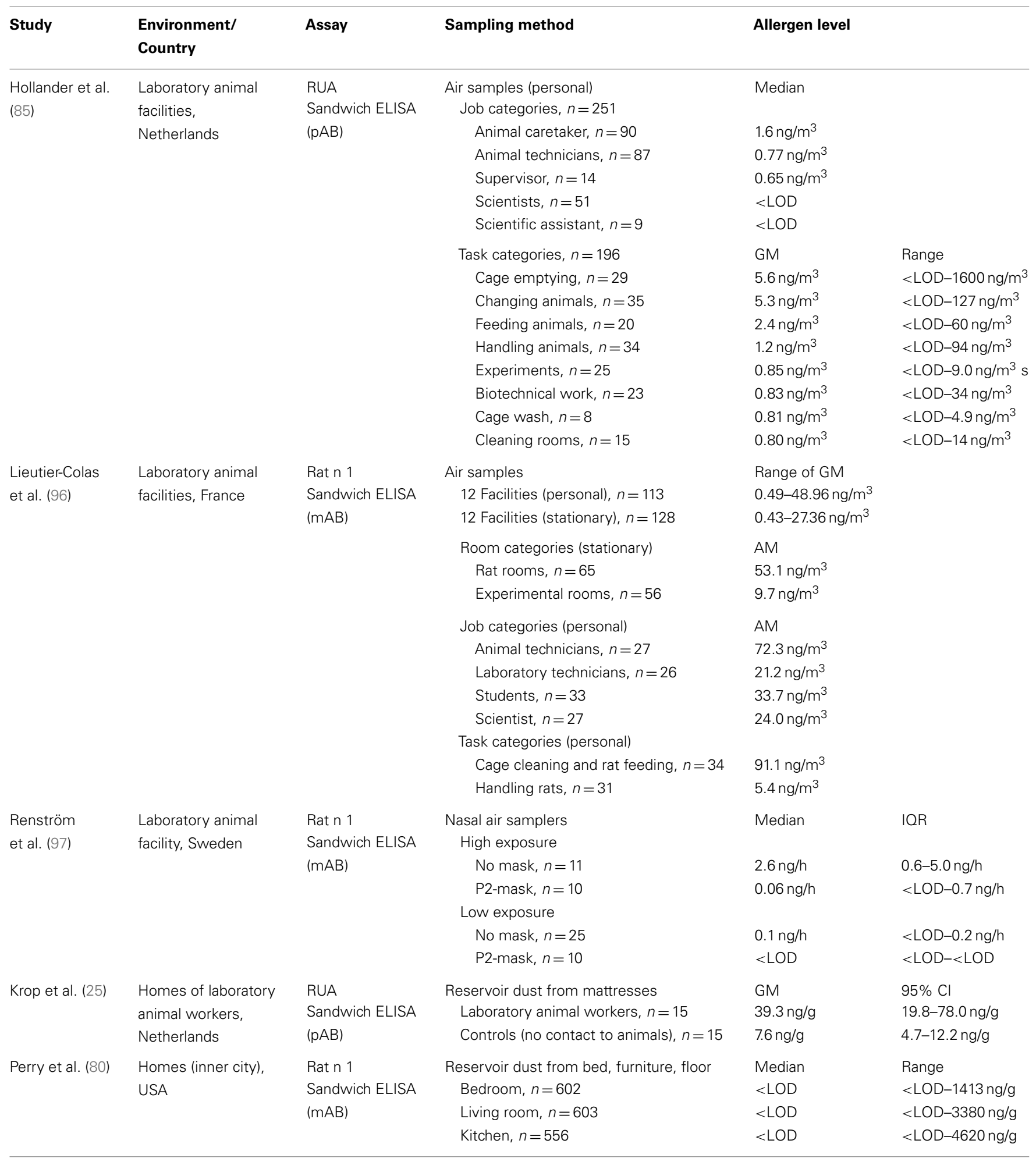

$R \cup A$, rat urinary allergens; $P A B$, polyclonal antibodies; $A M$, arithmetic mean; $G M$, geometric mean; IQR, interquartile range; $C l$, confidence interval; $L O D$, limit of detection.

retrospective study of horse allergy revealed a sensitization rate of $2.7 \%$ in a population of 23,460 children who underwent skin prick testing (101). A recent Italian multicenter study in an urban population with respiratory allergy reported that the prevalence of sensitization to horse dander was $5.38 \%$ among atopic subjects (102). Only $27 \%$ of horse-sensitized patients reported direct 
contact with the animals. Therefore, the authors of both studies recommended that the horse allergen be included in the standard panel for the diagnosis of respiratory allergy.

Several horse allergens have been identified and characterized, with Equ c 1 reported as the most important. Equ $\mathrm{c} 1$ is found at high concentrations in dander and saliva, as well as in small quantities in urine (103). The 22-kDa glycoprotein belongs to the lipocalin family (104) and has surfactant properties (105). The other proteins, Equ c 2, lipocalin (16 kDa); Equ c 3, horse serum albumin (65 kDa); Equ c $4(18.7 \mathrm{kDa})$; and Equ c $5(16.7 \mathrm{kDa})$, both latherins, were classified as minor allergens $(11,50)$. The analysis of the allergenic composition of horse dander from several breeds showed considerable inter-breed and within-breed variations but no breed-specific allergens (106). Moreover, all dander extracts contained the most important allergens.

The dispersion of horse allergens have been studied in different environments, including stables and their immediate surroundings as well as in public places such as schools and day-care centers (Table 5). Most of these studies were performed in Sweden, where the rate of horse ownership is high and horseback riding has become increasingly popular. To detect horse allergen in environmental samples, a sandwich ELISA based on monoclonal antibodies was developed and established by Emenius et al. (107). The two monoclonal antibodies, 103 and 14G4, were produced against horse dander extract, and recognize different epitopes of the same molecule, but the target protein was not further characterized. Immunoblotting analysis demonstrated antibody binding to a protein of around $16 \mathrm{kDa}(108)$. However, the horse allergen could not be identified because Equ c 2, Equ c 4, and Equ c 5 are within similar molecular weight range. Therefore, the ELISA assay is often referred to as Equ c $x$ in the literature. In 2009, Emenius et al. (109) assumed that the antibodies recognize the allergen Equ c 4, but further identification is necessary. The horse allergen assay is in the meantime, commercially available and provided as Equ c 4 ELISA (Indoor Biotechnologies) with horse hair extract as the calibration standard. All the studies described below used this monoclonal assay with minor modifications (different standards and detection limits). Allergen concentrations are expressed as units per milliliter, where 1 unit is equal to 1 ng protein of the horse standard.

The first study performed to detect horse allergen in the environment assessed airborne allergen levels at different distances from the stable (107). As expected, the highest allergen concentrations were measured inside the stable, and were approximately 500-fold higher than levels measured outdoors at the stable entrance. The levels of horse allergen declined rapidly with increasing distance from the stable and were not detected in air samples collected $40 \mathrm{~m}$ from the stable. A similar dispersal pattern was obtained with settled dust samples collected from hard surfaces wiped with compresses (allergen levels not stated). The dispersion of airborne horse allergen around the stable was also analyzed by Elfman et al. (108) during different seasons. The authors additionally investigated the influence of weather conditions such as temperature, relative and absolute humidity, wind speed and direction, and reported that horse allergen generally spread about $50 \mathrm{~m}$ from the stable and outdoor areas where horses were kept (e.g., pastures, riding grounds $=$ source area). Depending on wind speed and direction, low levels of horse allergen $\left(2-4 \mathrm{U} / \mathrm{m}^{3}\right)$ were sometimes detected at distances up to $500 \mathrm{~m}$ from the source area. Allergen levels did not correlate to air temperature or humidity, but were influenced by the seasons; concentrations in winter were lower than in summer. At the stable entrance, the median level in summer was 316 and $123 \mathrm{U} / \mathrm{m}^{3}$ in winter, and in the source area 16 and $8.3 \mathrm{U} / \mathrm{m}^{3}$, respectively. More rain in autumn and a frozen ground in winter were mentioned as possible explanations for the reduced levels of airborne allergen. The rapid decrease in horse allergen with increasing distance from the stable was confirmed by analyzing settled dust collected with electrostatic cloths. All but one sample collected $100 \mathrm{~m}$ from the source area were below the detection limit.

Further research by Emenius et al. (109) examined the transfer of horse allergen into homes located near the stables. In apartments, Petri dishes were placed indoors (living rooms) or outdoors (balconies). Only 6 out of 45 indoor samples had detectable horse allergen levels (three families with horse contact) and 16 out of 26 outdoor samples were positive. Indoor levels were about 1-2\% of the outdoor levels. In the second part of this study, the dispersion of allergens was investigated using a very unusual method. At different distances from a horse track, aspen leaves were collected and then extracted. The allergen level at $1 \mathrm{~m}$ from the track was set to $100 \%$. At a distance of $25 \mathrm{~m}$ from the track, $<10 \%$ of the original allergen concentration was found. In conclusion, horse allergens seem to disperse poorly through the air as allergen levels drop quickly with increasing distance from the source.

The presence of horse allergens in schools was first investigated by Kim et al. (110). Settled dust from desks, chairs, and floors was collected from 8 primary schools and 23 classrooms $(n=92)$ in Sweden. Horse allergens were found at high levels in most classrooms (median $945 \mathrm{U} / \mathrm{g}$ ), and asthma and respiratory symptoms were more common in schools where higher levels of horse allergens were measured. No information on the prevalence of horse ownership in the families was available, but common horse contact was expected due to the geographical region (rural suburb of Uppsala). These data were used for two further projects to compare the school environment in China (111) and Korea (112) using the same sampling strategy (settled dust) and analysis method (Equ $c \times$ ELISA). In contrast to Swedish classrooms, none of the Chinese samples ( $n=78,39$ classrooms) contained horse allergen. In Korea, horse allergen was only detected in one sample $(n=68,34$ classrooms).

The aim of another study was to investigate the correlation between horse allergen levels in schools and the number of children, who came into contact with horses in their leisure time (113). Petri dish and vacuumed dust samples were collected in 116 classrooms from 35 primary and secondary schools situated in inner-cities and in rural locations (county of Uppsala). In classrooms where many children had regular horse contact $(>12 \%)$, the levels of horse allergen were significantly higher (for both sampling methods) than in classrooms where children reported less or no contact. Furthermore, weekly measurements with Petri dishes were performed in 20 classrooms during a 10-week period. The results showed that horse allergen levels were strongly variable during the 10-weeks and the authors recommended repeated measurements when assessing indoor allergen exposure. Horse allergen contamination was also common in Swedish day-care 
Table 5 | Studies related to exposure assessment to horse allergen.

\begin{tabular}{|c|c|c|c|c|c|}
\hline Study & $\begin{array}{l}\text { Environment/ } \\
\text { country }\end{array}$ & Assay & Sampling method & \multicolumn{2}{|l|}{ Allergen level } \\
\hline $\begin{array}{l}\text { Emenius } \\
\text { et al. (107) }\end{array}$ & $\begin{array}{l}\text { Inside and outside a } \\
\text { stable, Sweden }\end{array}$ & $\begin{array}{l}\text { Equ c } x \\
\text { Sandwich ELISA } \\
(\mathrm{mAB})\end{array}$ & $\begin{array}{l}\text { Air samples, } n=17 \\
\text { Inside the stable } \\
\text { Stable entrance } \\
\text { 10-20 m from stable } \\
40-500 \mathrm{~m} \text { from stable }\end{array}$ & $\begin{array}{l}\text { AM } \\
439000 \mathrm{U} / \mathrm{m}^{3} \\
1140 \mathrm{U} / \mathrm{m}^{3} \\
150 \mathrm{U} / \mathrm{m}^{3} \\
<\mathrm{LOD}\end{array}$ & \\
\hline $\begin{array}{l}\text { Elfman et al. } \\
\text { (108) }\end{array}$ & $\begin{array}{l}\text { Inside and outside a } \\
\text { stable, Sweden }\end{array}$ & $\begin{array}{l}\text { Equ c x } \\
\text { Sandwich ELISA } \\
(\mathrm{mAB})\end{array}$ & $\begin{array}{l}\text { Air samples (stationary) } \\
\text { Inside the stable, } n=12 \\
\text { Stable entrance, } n=10 \\
\text { Source area, } n=49 \\
50 \mathrm{~m} \text { from stable, } n=27 \\
100-500 \mathrm{~m} \text { from stable, } n=91 \\
\text { Electrostatic cloths, } n=29 \\
\text { Source area } \\
25-50 \mathrm{~m} \text { from stable } \\
>100 \mathrm{~m} \text { from stable }\end{array}$ & $\begin{array}{l}\text { Median } \\
4300 \mathrm{U} / \mathrm{m}^{3} \\
316 \mathrm{U} / \mathrm{m}^{3} \\
16 \mathrm{U} / \mathrm{m}^{3} \\
<\mathrm{LOD} \\
<\mathrm{LOD} \\
\text { Median } \\
27000 \mathrm{U} / \mathrm{m}^{2} \\
30000 \mathrm{U} / \mathrm{m}^{2} \\
<\mathrm{LOD}\end{array}$ & 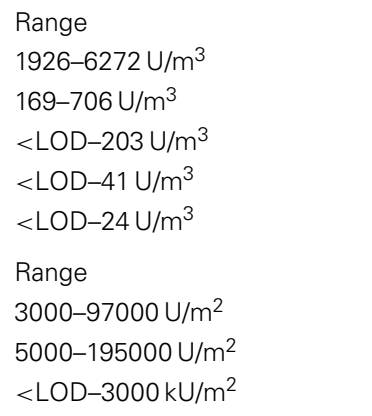 \\
\hline $\begin{array}{l}\text { Emenius } \\
\text { et al. (109) }\end{array}$ & $\begin{array}{l}\text { Homes nearby } \\
\text { stables, vicinity of a } \\
\text { horse track, Sweden }\end{array}$ & $\begin{array}{l}\text { Equ } c x \\
\text { Sandwich ELISA } \\
(\mathrm{mAB})\end{array}$ & $\begin{array}{l}\text { Petri dishes (14 days) } \\
\text { Indoors (living rooms), } n=45 \\
\text { Outdoors (balconies), } n=26 \\
\text { Aspen leaves } \\
1 \mathrm{~m} \text { from horse track } \\
10 \mathrm{~m} \text { from horse track } \\
25 \mathrm{~m} \text { from horse track } \\
\text { No horse track }\end{array}$ & $\begin{array}{l}\text { Positive sample } \\
6 \text { (Apartments } \\
\text { with horse } \\
16 \text { (15 Apartme } \\
\text { Allergen level } \\
100 \% \\
31-37 \% \\
8-9 \% \\
\text { None }\end{array}$ & $\begin{array}{l}<n \\
<20 m \text { from stable or families } \\
\text { ontact) } \\
\text { nts }<250 \text { m from stable) }\end{array}$ \\
\hline $\begin{array}{l}\text { Kim et al. } \\
(110)\end{array}$ & Schools, Sweden & $\begin{array}{l}\text { Equ c } x \\
\text { Sandwich ELISA } \\
(\mathrm{mAB})\end{array}$ & $\begin{array}{l}\text { Reservoir dust from desks, chairs and } \\
\text { floor, } n=92\end{array}$ & $\begin{array}{l}\text { Median } \\
945 \mathrm{U} / \mathrm{g}\end{array}$ & $\begin{array}{l}\text { Range } \\
<\text { LOD-31000 U/g }\end{array}$ \\
\hline $\begin{array}{l}\text { Merrit et al. } \\
(113)\end{array}$ & Schools, Sweden & $\begin{array}{l}\text { Equ c } x \\
\text { Sandwich ELISA } \\
(\mathrm{mAB})\end{array}$ & $\begin{array}{l}\text { Reservoir dust from furniture and floor } \\
\begin{array}{l}\text { Total, } n=116 \\
\text { Classes }>12 \% \text { horse contact } \\
\text { Classes }<12 \% \text { horse contact } \\
\text { Petri dishes ( } 14 \text { days) } \\
\text { Total, } n=116 \\
\text { Classes }>12 \% \text { horse contact } \\
\text { Classes }<12 \% \text { horse contact }\end{array}\end{array}$ & $\begin{array}{l}\text { GM } \\
1343 \mathrm{U} / g \\
2051 \mathrm{U} / \mathrm{g} \\
880 \mathrm{U} / \mathrm{g} \\
\mathrm{GM} \\
73.9 \mathrm{U} / \mathrm{m}^{2} / \text { day } \\
96.2 \mathrm{U} / \mathrm{m}^{2} / \text { day } \\
65.7 \mathrm{U} / \mathrm{m}^{2} / \text { day }\end{array}$ & \\
\hline Cai et al. (67) & $\begin{array}{l}\text { Day-care centers, } \\
\text { Sweden }\end{array}$ & $\begin{array}{l}\text { Equ c x } \\
\text { Sandwich ELISA } \\
(\mathrm{mAB})\end{array}$ & $\begin{array}{l}\text { Petri dishes (30-40 days) } \\
\text { Diverse rooms, } n=97\end{array}$ & $\begin{array}{l}\mathrm{GM} \\
5 \mathrm{U} / \mathrm{m}^{2} / \text { day }\end{array}$ & $\begin{array}{l}\text { Range } \\
<\text { LOD-208.7 U/m²/day }\end{array}$ \\
\hline
\end{tabular}

mAB, monoclonal antibodies; GM, geometric mean; $L O D$, limit of detection; $A M$, arithmetic mean.

centers (67), where allergen was detected in $63 \%$ of Petri dish dust samples with geometric mean of $5 \mathrm{ng} / \mathrm{m}^{2} /$ day.

\section{CATTLE (BOS DOMESTICUS)}

Cattle allergy is almost exclusively associated with occupational exposure and occurs primarily in cattle farmers. Studies in Scandinavian countries found that $5-20 \%$ of farmers are sensitized to cattle allergens (114-116). Moreover, the German Cattle Allergy
Study has indicated that $9.1 \%$ of 5627 farmers with occupational airway diseases were due to cattle allergies (117). The effect of the farming environment on sensitization to different allergens was investigated in children (118) and adults (119). For both, no significant differences were observed with respect to sensitization against most of the common allergens (e.g., house dust mites, pets, pollens). Only cattle sensitization was more prevalent among subjects living on farms compared with those not living on farms. 
The main sources of bovine allergens are cow hair and dander, but allergens are also found in urine, saliva, whey, amniotic fluid, and beef (120). Early investigations of bovine materials have found 17 different antigenic components, several of which have been currently identified and characterized as allergens. The lipocalin Bos d 2 is the major respiratory allergen in cow dander $(121,122)$, with several isoforms in existence (123). It is produced in the sweat glands and transported to the skin surface as a carrier of pheromones (124). Other bovine allergens are: Bos d $3(11 \mathrm{kDa})$, calcium-binding protein; Bos d 4 (14 kDa), $\alpha$-lactoglobulin; Bos d 5 (18 kDa), $\beta$-lactoglobulin; Bos d $6(67 \mathrm{kDa})$, serum albumin; Bos d $7(150 \mathrm{kDa})$, immunoglobulin; and Bos d 8 (19-25 kDa), caseins $(11,50)$. Bos d 4, 5, and 8 are major allergens in cow's milk and play an important role in food allergy (125).

Measurements of epithelial bovine allergens have been carried out mainly in occupational settings, stables and homes of farmers (Table 6). To quantify allergen concentrations, several different methods have been developed including: (1) ELISA inhibition with polyclonal antibodies against bovine skin scrape (126), (2) Rocket immunoelectrophoresis with rabbit antiserum against the major allergen Bos d 2 (127), (3) sandwich ELISA with polyclonal antibodies against an extract prepared from hair of different cattle breeds (128), and (4) sandwich ELISA with anti-Bos d 2 monoclonal antibodies 3D4 and mAB1 (129). Recently, the last method with recombinant Bos d 2 as a reference standard was made commercially available (Indoor Biotechnologies).

In cow stables, levels of bovine allergen were estimated in airborne dust $(129,130)$ as well as in settled dust samples $(128,131)$. All studies reported very high and strongly variable allergen concentrations. Allergen levels differed up to 200-fold between stables and were about 1000-fold higher than in homes. Virtanen et al. (133) examined the long-term variability in airborne allergen concentrations and found that in some cow stables, bovine allergen levels tend to be low, whereas in others the levels are consistently high. These variations are likely explained by factors associated with stable characteristics, such as size, heating, ventilation, and construction details of the building. Measurements of bovine allergens were also performed in stables of other animals (128). Whereas, only trace amounts of allergens were detectable in horse, sheep, pig, and chicken stables, goat stables had slightly increased allergen levels, most likely due to cross-reactivity between cow and goat epithelia.

The presence of cattle allergens in homes of dairy farmers was initially investigated by Hinze et al. (127). Floor dust samples were collected in different rooms of homes from patients with cow hair asthma and analyzed for Bos d 2 using Rocket immunelectrophoresis. The quantities of Bos $\mathrm{d} 2$ detected were dependent on the architectural setup and floor cover. The separation of barn and living quarters (not in the same building) led to a marked reduction in Bos d 2 levels in house dust. Bos $\mathrm{d} 2$ concentrations were also considerably lower in carpets than on tiles or linoleum. Furthermore, high indoor Bos d 2 levels were shown to correlate with the degree of IgE sensitization.

Using the same analytical methods, allergen levels in homes were analyzed in relation to the exposure intensity of cattle farmers (131). Farmers with occupational asthma or rhinitis caused by cow dander were divided into three groups: (1) no contact with cattle (giving-up the cattle husbandry for at least 2 years), (2) indirect exposure through family members, and (3) regular contact with cattle. The results showed a highly significant association between level of exposure and level of allergen. The terminating or limiting contact to cows reduced Bos $\mathrm{d} 2$ concentrations in both living room and mattress dust. The aim of a further study was to assess bovine allergen exposure in homes of cattle farmers by sampling settled airborne dust using electrostatic cloths (128). Cow hair allergens measured by polyclonal antibody-based ELISA were detected with a wide variation among the individual samples $\left(0.3-900 \mu \mathrm{g} / \mathrm{m}^{2}\right)$. The results, categorized by room type, showed significantly higher allergen concentrations in changing rooms compared with living rooms, bedrooms, or kitchens. As a control, dust sampling was also performed in urban dwellings. Interestingly, although none of the household members had any contact with cattle farms, the majority of urban samples were positive in the assay, though at very low concentrations. The median of $0.2 \mu \mathrm{g} / \mathrm{m}^{2}$ was 100 -fold lower in comparison to farmer homes. Because, the dispersal of cattle allergens from rural to urban environments through the ambient air was quite implausible, the authors supposed that the positive results were caused by the cross-reactivity between human and pet hair or by the presence of bovine allergens derived from foods such as milk and beef. Follow-up analysis using monoclonal antibodybased ELISA (Indoor Biotechnologies) confirmed the presence of the major respiratory allergen Bos $\mathrm{d} 2$ in these dust samples and extracts from foods [(134), EAACI abstract].

Finally, the distribution of cattle allergens was assessed at different distances to dairy facilities (132). The study was conducted in the Yakima Valley, Washington State, USA, where over 60 industrial scale dairies operate. Airborne samples were collected inside and outside homes and analyzed using Bos d 2 ELISA (Indoor Biotechnologies). Homes with resident dairy facility workers or cows on the premises were excluded to minimize the influence of occupational exposures on indoor environments. Similar to studies of dispersion of horse allergen, an allergen concentration gradient was observed. Outdoor and indoor results for airborne Bos d 2 showed the highest concentrations at proximal homes closest to dairies (within a $1 / 4$ mile, $0.4 \mathrm{~km}$ ), and lowest concentrations in distal homes farthest from dairies ( $>3$ miles, $4.8 \mathrm{~km}$ ). Median outdoor levels of Bos d 2 were significantly higher at proximal and intermediate homes compared with indoor levels.

\section{SUMMARY}

Measurements of animal allergens have been extensively performed during the past few decades. Allergen exposure to animal allergens occurs in a wide range of indoor environments including homes, educational facilities, workplaces, and different kind of public buildings and modes of public transportation. Mostly, settled dust and airborne dust samples were collected to measure animal allergen levels. The variability of allergen concentrations in a particular environment is high and dependent on numerous factors, the most important being the presence of animals. Highest allergen levels have generally been found in homes with pets, laboratory animal facilities housing mice or rats, and cow or horse stables. However, high allergen levels have also been frequently detected in locations where no animals reside (e.g., schools and public places), most likely due to passive transfer via human 
Table 6 | Studies related to exposure assessment to cattle allergens.

\begin{tabular}{|c|c|c|c|c|c|}
\hline Study & Environment/country & Assay & Sampling method & Allergen level & \\
\hline \multirow{3}{*}{$\begin{array}{l}\text { Virtanen et al. } \\
\text { (130) }\end{array}$} & \multirow[t]{3}{*}{ Stables, Finland } & Bovine epithelial antigen & Air samples (stationary) & AM & Range \\
\hline & & ELISA inhibition & Feeding passage, $n=18$ & $350 \mathrm{ng} / \mathrm{m}^{3}$ & $40-2700 \mathrm{ng} / \mathrm{m}^{3}$ \\
\hline & & $(\mathrm{pAB})$ & Manure passage, $n=18$ & $730 \mathrm{ng} / \mathrm{m}^{3}$ & $40-9500 \mathrm{ng} / \mathrm{m}^{3}$ \\
\hline \multirow{2}{*}{$\begin{array}{l}\text { Ylönen et al. } \\
\text { (129) }\end{array}$} & \multirow[t]{2}{*}{ Stables, Finland } & \multirow[t]{2}{*}{ Bos d 2 Sandwich ELISA (mAB) } & Air samples (stationary) & AM & Range \\
\hline & & & Stables, $n=19$ & $280 \mathrm{ng} / \mathrm{m}^{3}$ & $54-804$ ng/m³ \\
\hline \multirow{10}{*}{$\begin{array}{l}\text { Hinze et al. } \\
(127)\end{array}$} & \multirow{10}{*}{$\begin{array}{l}\text { Homes of farmers, } \\
\text { Germany }\end{array}$} & \multirow{10}{*}{$\begin{array}{l}\text { Bos d } 2 \text { Rocket immunelectrophoresis } \\
\text { (pAB) }\end{array}$} & Reservoir dust from floor & \multirow[t]{3}{*}{ AM } & \\
\hline & & & Barn and living quarters & & \\
\hline & & & Separated & & \\
\hline & & & Corridor, $n=17$ & \multicolumn{2}{|l|}{$40.6 \mu \mathrm{g} / \mathrm{g}$} \\
\hline & & & Living room, $n=17$ & \multicolumn{2}{|l|}{$82.4 \mu \mathrm{g} / \mathrm{g}$} \\
\hline & & & Bedroom, $n=16$ & \multirow[t]{2}{*}{$56.3 \mu \mathrm{g} / \mathrm{g}$} & \\
\hline & & & In the same building & & \\
\hline & & & Corridor, $n=13$ & \multicolumn{2}{|l|}{$103.6 \mu \mathrm{g} / \mathrm{g}$} \\
\hline & & & Living room, $n=13$ & \multicolumn{2}{|l|}{$112.1 \mu \mathrm{g} / \mathrm{g}$} \\
\hline & & & Bedroom, $n=13$ & \multicolumn{2}{|l|}{$150.4 \mu \mathrm{g} / \mathrm{g}$} \\
\hline \multirow{10}{*}{$\begin{array}{l}\text { Berger et al. } \\
(131)\end{array}$} & \multirow{3}{*}{$\begin{array}{l}\text { Stables and homes of } \\
\text { farmers (three groups } \\
\text { with different cattle }\end{array}$} & \multirow{3}{*}{$\begin{array}{l}\text { Bos d } 2 \text { Rocket immunelectrophoresis } \\
\text { (pAB) }\end{array}$} & Reservoir dust & \multirow{3}{*}{$\begin{array}{l}\text { Median } \\
20,400 \mu \mathrm{g} / \mathrm{g}\end{array}$} & \multirow{3}{*}{$\begin{array}{l}\text { Range } \\
680-55,400 \mu \mathrm{g} / \mathrm{g}\end{array}$} \\
\hline & & & Stables, $n=36$ & & \\
\hline & & & Homes (living room floor) & & \\
\hline & \multirow[t]{7}{*}{ exposure), Germany } & & Former contact, $n=10$ & $13 \mu \mathrm{g} / \mathrm{g}$ & $3-43 \mu \mathrm{g} / \mathrm{g}$ \\
\hline & & & Indirect contact, $n=13$ & $148 \mu \mathrm{g} / \mathrm{g}$ & $34-2929 \mu \mathrm{g} / \mathrm{g}$ \\
\hline & & & Direct contact, $n=23$ & $316 \mu \mathrm{g} / \mathrm{g}$ & $46-4209 \mu \mathrm{g} / \mathrm{g}$ \\
\hline & & & Homes (mattress) & & \\
\hline & & & Former contact, $n=10$ & $12 \mu \mathrm{g} / \mathrm{g}$ & $4-381 \mu \mathrm{g} / \mathrm{g}$ \\
\hline & & & Indirect contact, $n=13$ & $195 \mu \mathrm{g} / \mathrm{g}$ & $15-403 \mu \mathrm{g} / \mathrm{g}$ \\
\hline & & & Direct contact, $n=23$ & $265 \mu \mathrm{g} / \mathrm{g}$ & $31-1268 \mu \mathrm{g} / \mathrm{g}$ \\
\hline \multirow{8}{*}{$\begin{array}{l}\text { Zahradnik } \\
\text { et al. (128) }\end{array}$} & \multirow{8}{*}{$\begin{array}{l}\text { Stables and homes of } \\
\text { farmers and controls, } \\
\text { Germany }\end{array}$} & \multirow{8}{*}{$\begin{array}{l}\text { Cow hair allergen } \\
\text { Sandwich ELISA } \\
\text { (pAB) }\end{array}$} & Electrostatic cloths (14 days) & \multirow[t]{2}{*}{ Median } & Range \\
\hline & & & Stables & & \\
\hline & & & Cow, $n=37$ & $51,700 \mu \mathrm{g} / \mathrm{m}^{2}$ & $4760-559,000 \mu \mathrm{g} / \mathrm{m}^{2}$ \\
\hline & & & Goat, $n=6$ & $315.7 \mu \mathrm{g} / \mathrm{m}^{2}$ & $91-701.4 \mu \mathrm{g} / \mathrm{m}^{2}$ \\
\hline & & & Other, $n=14$ & $1.2 \mu \mathrm{g} / \mathrm{m}^{2}$ & $<\mathrm{LOD}-6.5 \mu \mathrm{g} / \mathrm{m}^{2}$ \\
\hline & & & Homes & & \\
\hline & & & Cattle farmers, $n=128$ & $22.6 \mu \mathrm{g} / \mathrm{m}^{2}$ & $0.3-900 \mu \mathrm{g} / \mathrm{m}^{2}$ \\
\hline & & & Urban dwellers, $n=32$ & $0.2 \mu \mathrm{g} / \mathrm{m}^{2}$ & $<\mathrm{LOD}-2.7 \mu \mathrm{g} / \mathrm{m}^{2}$ \\
\hline Williams et al. & Inside and outside of & Bos d 2 & Air samples (stationary) & Median & Maximum \\
\hline$(132)$ & homes nearby dairy & Sandwich ELISA & Indoor & & \\
\hline & facilities, USA & $(\mathrm{mAB})$ & Proximal, $n=16$ & $0.12 \mu \mathrm{g} / \mathrm{m}^{3}$ & $0.97 \mu \mathrm{g} / \mathrm{m}^{3}$ \\
\hline & & & Intermediate, $n=5$ & $0.01 \mu \mathrm{g} / \mathrm{m}^{3}$ & $0.12 \mu \mathrm{g} / \mathrm{m}^{3}$ \\
\hline & & & Distal, $n=12$ & $0.01 \mu \mathrm{g} / \mathrm{m}^{3}$ & $0.03 \mu \mathrm{g} / \mathrm{m}^{3}$ \\
\hline & & & Outdoor & & \\
\hline & & & Proximal, $n=19$ & $0.66 \mu \mathrm{g} / \mathrm{m}^{3}$ & $1.87 \mu \mathrm{g} / \mathrm{m}^{3}$ \\
\hline & & & Intermediate, $n=6$ & $0.17 \mu \mathrm{g} / \mathrm{m}^{3}$ & $0.29 \mu \mathrm{g} / \mathrm{m}^{3}$ \\
\hline & & & Distal, $n=12$ & $0.01 \mu \mathrm{g} / \mathrm{m}^{3}$ & $0.10 \mu \mathrm{g} / \mathrm{m}^{3}$ \\
\hline
\end{tabular}

mAB, monoclonal antibodies; $p A B$, polyclonal antibodies; $L O D$, limit of detection; $A M$, arithmetic mean.

clothing or hair. Some studies have demonstrated that animal allergen levels in these mostly public environments can be significantly higher than in domestic areas without animals. The number of pet owners is one of the strongest predictors of increased allergen levels in these settings. Apart from the presence of animals or number of individuals with direct and frequent contact to animals, differences in allergen concentrations are associated with various building-related factors such as size and type of room, type of flooring, and furniture, cleaning frequency, ventilation system, and also the distance to animal rooms or stables. For example, carpets, mattresses, and upholstery are consistently found to have much higher concentrations of animal allergens than smooth surfaces. 
Allergen levels can also vary in different parts of the world, which appears to be primarily influenced by regional and cultural differences in pet ownership or livestock farming. Rodent infestation is another factor that is strongly associated with increased mouse allergen levels. In contrast to mites, mammalian allergens seem to be independent of climate or seasonal variations.

Besides environmental factors, sample collection strategies and analytic methods enormously influence the results of exposure measurements. A variety of commercially available and wellcharacterized sampling equipment have been used in the studies. For each sampling method, differences exist regarding features, such as sampling pump, air flow rate, vacuum power, collection device, filter type, sampling duration and number, and size and type of surfaces sampled. Concerning the ELISA method, which was used to quantify allergen concentrations, the variations comprise the type of antibodies, calibration standard and its protein determination, replicate precision, and detection/visualization methods. Differences in data analysis for example, median, arithmetic, or geometric mean and calculation of the results as nanograms per gram or nanograms per meter square impede the direct comparison of the data produced in different studies.

\section{CONCLUSION AND RECOMMENDATIONS}

Environmental allergen exposure plays a significant role in the development of asthma and allergy. Allergic diseases are important public health concerns because of severity of symptoms, reduced quality of life, and limited productivity of the affected persons and high healthcare costs. Therefore, the identification of major sites of exposure and factors influencing allergen levels is essential to prevent allergic health effects. Specific measures to reduce or to avoid exposure to allergens can be initiated. Moreover, the knowledge of exposure levels is helpful to estimate the risk of sensitization or induction of symptoms in occupational or environmental settings. There is still lack of information on risk limits. One reason is the complexity of allergen monitoring, which is a multi-step task requiring various tools and techniques. Although, more allergen exposure data and more accurate methods are becoming available, a general standardization of sampling, and analytical procedures is much needed. The development of consensus protocols can be advantageous in the future for a better comparison of data from different studies. In the case of animal allergens, one basic requirement for standardization is fulfilled through commercial availability of monoclonal sandwich ELISA/MARIA kits for the detection of major allergens. Some assays, e.g., Fel d 1 and Can $\mathrm{f} 1$ ELISA, have already reached global dissemination.

Apart from methodological issues, the estimation of "general" risk levels is complex. In contrast to toxic substances, which affect more or less all exposed individuals, the reactivity to the same allergen can vary extremely between people. Some persons will never become sensitized even at high exposure. Allergen levels associated with an increased risk of disease and/or sensitization are certainly different for healthy, sensitized and allergic persons. Finally, the determination of risk levels should also include the type of environment (workplace, home, school) because the circumstances of personal exposure are different. Therefore, a clear definition of strategy which provides the best proxy of allergen burden for different exposure scenarios is needed. The definition should include the type of dust, dust sampling procedure with validated protocol, type of allergenic substances (allergen mix or single allergen) and standardized immunoassay.

\section{REFERENCES}

1. Platts-Mills TA, Vervloet D, Thomas WR, Aalberse RC, Chapman MD. Indoor allergens and asthma: report of the third international workshop. J Allergy Clin Immunol (1997) 100(6 Pt 1):S2-24. doi:10.1016/S0091-6749(97)70292-6

2. Arshad SH. Does exposure to indoor allergens contribute to the development of asthma and allergy? Curr Allergy Asthma Rep (2010) 10(1):49-55. doi:10.1007/s11882-009-0082-6

3. Phillips JF, Lockey RF. Exotic petallergy. J Allergy Clin Immunol (2009) 123(2):513-5. doi:10.1016/j.jaci.2008.09.019

4. Pecquet C. New pets and allergies. Eur J Dermatol (2012) 22(1):14-22. doi:10.1684/ejd.2011.1555

5. Heinzerling LM, Burbach GJ, Edenharter G, Bachert C, Bindslev-Jensen C, Bonini S, et al. GA 2 LEN skin test study I: GA ${ }^{2} \mathrm{LEN}$ harmonization of skin prick testing: novel sensitization patterns for inhalant allergens in Europe. Allergy (2009) 64(10):1498-506. doi:10.1111/j.1398-9995.2009.02093.x

6. Díaz-Perales A, González-de-Olano D, Pérez-Gordo M, Pastor-Vargas C. Allergy to uncommon pets: new allergies but the same allergens. Front Immunol (2013) 4:492. doi:10.3389/fimmu.2013.00492

7. Bush RK, Stave GM. Laboratory animal allergy: an update. ILAR J (2003) 44(1):28-51. doi:10.1093/ilar.44.1.28

8. Virtanen T, Kinnunen T, Rytkönen-Nissinen M. Mammalian lipocalin allergens - insights into their enigmatic allergenicity. Clin Exp Allergy (2012) 42(4):494-504. doi:10.1111/j.1365-2222.2011.03903.x

9. Spitzauer S, Pandjaitan B, Söregi G, Mühl S, Ebner C, Kraft D, et al. IgE cross-reactivities against albumins in patients allergic to animals. J Allergy Clin Immunol (1995) 96(6 Pt 1):951-9. doi:10.1016/S0091-6749(95)70233-4

10. Liccardi G, Asero R, D’Amato M, D’Amato G. Role of sensitization to mammalian serum albumin in allergic disease. Curr Allergy Asthma Rep (2011) 11(5):421-6. doi:10.1007/s11882-011-0214-7

11. Hilger C, Kuehn A, Hentges F. Animal lipocalin allergens. Curr Allergy Asthma Rep (2012) 12(5):438-47. doi:10.1007/s11882-012-0283-2

12. Custovic A, Simpson A, Pahdi H, Green RM, Chapman MD, Woodcock A. Distribution, aerodynamic characteristics, and removal of the major cat allergen Fel d 1 in British homes. Thorax (1998) 53(1):33-8. doi:10.1136/thx.53.1.33

13. Arlian LG, Neal JS, Morgan MS, Rapp CM, Clobes AL. Distribution and removal of cat, dog and mite allergens on smooth surfaces in homes with and without pets. Ann Allergy Asthma Immunol (2001) 87(4):296-302. doi:10.1016/S10811206(10)62243-0

14. Wood RA, Chapman MD, Adkinson NF, Eggleston PA. The effect of cat removal on allergen content in household-dust samples. J Allergy Clin Immunol (1989) 83(4):730-4. doi:10.1016/0091-6749(89)90006-7

15. Bush RK, Wood RA, Eggleston PA. Laboratory animal allergy. J Allergy Clin Immunol (1998) 102(1):99-112. doi:10.1016/S0091-6749(98)70060-0

16. de Blay F, Heymann PW, Chapman MD, Platts-Mills TA. Airborne dust mite allergens: comparison of group II allergens with group I mite allergen and cat-allergen Fel d I. J Allergy Clin Immunol (1991) 88(6):919-26. doi:10.1016/0091-6749(91)90249-N

17. Martin IR, Wickens K, Patchett K, Kent R, Fitzharris P, Siebers R, et al. Cat allergen levels in public places in New Zealand. NZMed J (1998) 111(1074):356-8.

18. Almqvist C, Wickman M, Perfetti L, Berglind N, Renström A, Hedrén M, et al. Worsening of asthma in children allergic to cats, after indirect exposure to cat at school. Am J Respir Crit Care Med (2001) 163(3 Pt 1):694-8. doi:10.1164/ajrccm.163.3.2006114

19. Ritz BR, Hoelscher B, Frye C, Meyer I, Heinrich J. Allergic sensitization owing to 'second-hand' cat exposure in schools. Allergy (2002) 57(4):357-61. doi:10.1034/j.1398-9995.2002.1s3404.x

20. Patchett K, Lewis S, Crane J, Fitzharris P. Cat allergen (Fel d 1) levels on school children's clothing and in primary school classrooms in Wellington, New Zealand. J Allergy Clin Immunol (1997) 100(6 Pt 1):755-9. doi:10.1016/ S0091-6749(97)70269-0

21. Berge M, Munir AK, Dreborg S. Concentrations of cat (Fel d1), dog (Can f1) and mite (Der f1 and Der pl) allergens in the clothing and school environment of Swedish schoolchildren with and without pets at home. Pediatr Allergy Immunol (1998) 9(1):25-30. doi:10.1111/j.1399-3038.1998.tb00296.x 
22. de Lucca SD, O’Meara TJ, Tovey ER. Exposure to mite and cat allergens on a range of clothing items at home and the transfer of cat allergen in the workplace. JAllergy Clin Immunol (2000) 106(5):874-9. doi:10.1067/mai.2000. 110804

23. Egmar AC, Almqvist C, Emenius G, Lilja G, Wickman M. Deposition of cat (Fel d 1), dog (Can f 1), and horse allergen over time in public environments - a model of dispersion. Allergy (1998) 53(10):957-61. doi:10.1111/j.1398-9995. 1998.tb03796.x

24. Karlsson A-S, Renström A. Human hair is a potential source of cat allergen contamination of ambient air. Allergy (2005) 60(7):961-4. doi:10.1111/j.13989995.2005.00796.x

25. Krop EJM, Doekes G, Stone MJ, Aalberse RC, van der Zee JS. Spreading of occupational allergens: laboratory animal allergens on hair-covering caps and in mattress dust of laboratory animal workers. Occup Environ Med (2007) 64(4):267-72. doi:10.1136/oem.2006.028845

26. Renström A. Exposure to airborne allergens: a review of sampling methods. J Environ Monit (2002) 4(5):619-22. doi:10.1039/B202756A

27. Schram-Bijkerk D, Doekes G, Boeve M, Douwes J, Riedler J, Ublagger E, et al. Exposure to microbial components and allergens in population studies: a comparison of two house dust collection methods applied by participants and fieldworkers. Indoor Air (2006) 16(6):414-25. doi:10.1111/j.1600-0668.2006. 00435.x

28. Parvaneh S, Elfman L, Ahlf E, Nybom R, Elfman LH, van Hage-Hamsten M. A new method for collecting airborne allergens. Allergy (2000) 55(12):1148-54. doi:10.1034/j.1398-9995.2000.00652.x

29. Karlsson A-S, Hedrén M, Almqvist C, Larsson K, Renström A. Evaluation of Petri dish sampling for assessment of cat allergen in airborne dust. Allergy (2002) 57(2):164-8. doi:10.1034/j.1398-9995.2002.1s3297.x

30. Würtz H, Sigsgaard T, Valbjørn O, Doekes G, Meyer HW. The dustfall collector - a simple passive tool for long-term collection of airborne dust: a project under the Danish Mould in Buildings program (DAMIB). Indoor Air (2005) 15(Suppl 9):33-40. doi:10.1111/j.1600-0668.2005.00342.x

31. Noss I, Wouters IM, Visser M, Heederik Dick JJ, Thorne PS, Brunekreef B, et al. Evaluation of a low-cost electrostatic dust fall collector for indoor air endotoxin exposure assessment. Appl Environ Microbiol (2008) 74(18):5621-7. doi:10.1128/AEM.00619-08

32. Grier TJ. Laboratory methods for allergen extract analysis and quality control. Clin Rev Allergy Immunol (2001) 21 (2-3):111-40. doi:10.1385/CRIAI: 21:2-3:111

33. Chapman MD, Vailes LD, Ichikawa K. Immunoassays for indoor allergens. Clin Rev Allergy Immunol (2000) 18(3):285-300. doi:10.1385/CRIAI:18:3:285

34. Earle CD, King EM, Tsay A, Pittman K, Saric B, Vailes L, et al. High-throughput fluorescent multiplex array for indoor allergen exposure assessment. J Allergy Clin Immunol (2007) 119(2):428-33. doi:10.1016/j.jaci.2006.11.004

35. Eller E, Roll S, Chen C-M, Herbarth O, Wichmann H-E, Berg A, et al. Metaanalysis of determinants for pet ownership in 12 European birth cohorts on asthma and allergies: a GA 2 LEN initiative. Allergy (2008) 63(11):1491-8. doi:10.1111/j.1398-9995.2008.01790.x

36. Portnoy JM, Kennedy K, Sublett JL, Phipatanakul W, Matsui E, Barnes C, et al. Environmental assessment and exposure control: a practice parameter - furry animals. Ann Allergy Asthma Immunol (2012) 108(4):223.e1. doi:10.1016/j.anai.2012.02.015

37. Gruchalla RS, Pongracic J, Plaut M, Evans R III, Visness CM, Walter M, et al. Inner City Asthma Study: relationships among sensitivity, allergen exposure, and asthma morbidity. J Allergy Clin Immunol (2005) 115(3):478-85. doi:10.1016/j.jaci.2004.12.006

38. Haftenberger M, Laußmann D, Ellert U, Kalcklösch M, Langen U, Schlaud M, et al. Prävalenz von sensibilisierungen gegen inhalations- und nahrungsmittelallergene. Ergebnisse der Studie zur Gesundheit Erwachsener in Deutschland (DEGS1). Bundesgesundheitsblatt Gesundheitsforschung Gesundheitsschutz (2013) 56(5-6):687-97. doi:10.1007/s00103-012-1658-1

39. Aoyama K, Ueda A, Manda F, Matsushita T, Ueda T, Yamauchi C. Allergy to laboratory animals: an epidemiological study. Br J Ind Med (1992) 49(1):41-7.

40. Susitaival P, Kirk JH, Schenker MB. Atopic symptoms among California veterinarians. Am J Ind Med (2003) 44(2):166-71. doi:10.1002/ajim.10253

41. Chapman MD, Wood RA. The role and remediation of animal allergens in allergic diseases. J Allergy Clin Immunol (2001) 107(3):S414. doi:10.1067/mai. 2001.113672
42. Grönlund H, Saarne T, Gafvelin G, van Hage M. The major cat allergen, Fel d 1, in diagnosis and therapy. Int Arch Allergy Immunol (2010) 151(4):265-74. doi: $10.1159 / 000250435$

43. Kristensen AK, Schou C, Roepstorff P. Determination of isoforms, N-linked glycan structure and disulfide bond linkages of the major cat allergen Fel d 1 by a mass spectrometric approach. Biol Chem (1997) 378(8):899-908.

44. van Ree R, van Leeuwen W, Bulder I, Bond J, Aalberse RC. Purified natural and recombinant Fel d 1 and cat albumin in in vitro diagnostics for cat allerg. J Allergy Clin Immunol (1999) 104(6):1223-30. doi:10.1016/S0091-6749(99) 70017-5

45. Kaiser L, Velickovic TC, Badia-Martinez D, Adedoyin J, Thunberg S, Hallén D, et al. Structural characterization of the tetrameric form of the major cat allergen Fel d 1. J Mol Biol (2007) 370(4):714-27. doi:10.1016/j.jmb.2007.04.074

46. Dabrowski AJ, Van der Brempt X, Soler M, Seguret N, Lucciani P, Charpin D, et al. Cat skin as an important source of Fel d I allergen. J Allergy Clin Immunol (1990) 86(4 Pt 1):462-5. doi:10.1016/S0091-6749(05)80200-3

47. Charpin C, Mata P, Charpin D, Lavaut MN, Allasia C, Vervloet D. Fel d I allergen distribution in cat fur and skin. J Allergy Clin Immunol (1991) 88(1):77-82. doi:10.1016/0091-6749(91)90303-6

48. de Andrade AD, Birnbaum J, Magalon C, Magnol JP, Lanteaume A, Charpin D, et al. Fel d I levels in cat anal glands. Clin Exp Allergy (1996) 26(2):178-80. doi:10.1111/j.1365-2222.1996.tb00077.x

49. Jalil-Colome J, de Andrade AD, Birnbaum J, Casanova D, Mège JL, Lanteaume A, et al. Sex difference in Fel d 1 allergen production. J Allergy Clin Immunol (1996) 98(1):165-8. doi:10.1016/S0091-6749(96)70238-5

50. Virtanen T, Kinnunen T. Mammalian allergens. Clin Allergy Immunol (2008) 21:201-18. doi:10.3109/9781420061987.012

51. Konieczny A, Morgenstern JP, Bizinkauskas CB, Lilley CH, Brauer AW, Bond JF, et al. The major dog allergens, Can $\mathrm{f} 1$ and Can $\mathrm{f} 2$, are salivary lipocalin proteins: cloning and immunological characterization of the recombinant forms. Immunology (1997) 92(4):577-86. doi:10.1046/j.1365-2567.1997.00386.x

52. de Groot H, Goei KG, van Swieten P, Aalberse RC. Affinity purification of a major and a minor allergen from dog extract: serologic activity of affinitypurified Can $\mathrm{f}$ I and of Can f I-depleted extract. J Allergy Clin Immunol (1991) 87(6):1056-65. doi:10.1016/0091-6749(91)92150-Y

53. Ramadour M, Guetat M, Guetat J, El Biaze M, Magnan A, Vervloet D. Dog factor differences in Can $\mathrm{f} 1$ allergen production. Allergy (2005) 60(8):1060-4. doi:10.1111/j.1398-9995.2005.00824.x

54. Custovic A, Green R, Fletcher A, Smith A, Pickering CA, Chapman MD, et al. Aerodynamic properties of the major dog allergen Can $\mathrm{f}$ 1: distribution in homes, concentration, and particle size of allergen in the air. Am J Respir Crit Care Med (1997) 155(1):94-8. doi:10.1164/ajrccm.155.1.9001295

55. Vredegoor DW, Willemse T, Chapman MD, Heederik DJ, Krop EJ. Can f 1 levels in hair and homes of different dog breeds: lack of evidence to describe any dog breed as hypoallergenic. J Allergy Clin Immunol (2012) 130(4):904.e-9.e. doi:10.1016/j.jaci.2012.05.013

56. Chapman MD, Aalberse RC, Brown MJ, Platts-Mills TA. Monoclonal antibodies to the major feline allergen Fel d I. II. Single step affinity purification of Fel d I, N-terminal sequence analysis, and development of a sensitive two-site immunoassay to assess Fel d I exposure. J Immunol (1988) 140(3):812-8.

57. Ingram JM, Sporik R, Rose G, Honsinger R, Chapman MD, Platts-Mills TA. Quantitative assessment of exposure to $\operatorname{dog}($ Can f 1) and cat (Fel d 1) allergens: relation to sensitization and asthma among children living in Los Alamos, New Mexico. J Allergy Clin Immunol (1995) 96(4):449-56. doi:10.1016/S0091-6749(95)70286-5

58. Custovic A, Simpson B, Simpson A, Hallam C, Craven M, Woodcock A. Relationship between mite, cat, and dog allergens in reservoir dust and ambient air Allergy (1999) 54(6):612-6. doi:10.1034/j.1398-9995.1999.00062.x

59. Custis NJ, Woodfolk JA, Vaughan JW, Platts-Mills TAE. Quantitative measurement of airborne allergens from dust mites, dogs, and cats using an ioncharging device. Clin Exp Allergy (2003) 33(7):986-91. doi:10.1046/j.13652222.2003.01706.x

60. Arbes SJ, Cohn RD, Yin M, Muilenberg ML, Friedman W, Zeldin DC. Dog allergen (Can f 1) and cat allergen (Fel d 1) in US homes: results from the national survey of lead and allergens in housing. J Allergy Clin Immunol (2004) 114(1):111-7. doi:10.1016/j.jaci.2004.04.036

61. Heinrich J, Bedada GB, Zock J-P, Chinn S, Norbäck D, Olivieri M, et al. Cat allergen level: its determinants and relationship to specific IgE to cat 
across European centers. J Allergy Clin Immunol (2006) 118(3):674-81. doi:10.1016/j.jaci.2006.06.012

62. Simons E, Curtin-Brosnan J, Buckley T, Breysse P, Eggleston PA. Indoor environmental differences between inner city and suburban homes of children with asthma. J Urban Health (2007) 84(4):577-90. doi:10.1007/s11524-0079205-3

63. Bertelsen RJ, Instanes C, Granum B, Lødrup Carlsen KC, Hetland G, Carlsen K$\mathrm{H}$, et al. Gender differences in indoor allergen exposure and association with current rhinitis. Clin Exp Allergy (2010) 40(9):1388-97. doi:10.1111/j.13652222.2010.03543.x

64. Perzanowski MS, Rönmark E, Nold B, Lundbäck B, Platts-Mills TA. Relevance of allergens from cats and dogs to asthma in the northernmost province of Sweden: schools as a major site of exposure. J Allergy Clin Immunol (1999) 103(6):1018-24. doi:10.1016/S0091-6749(99)70173-9

65. Arbes SJ, Sever M, Mehta J, Collette N, Thomas B, Zeldin DC. Exposure to indoor allergens in day-care facilities: results from 2 North Carolina counties. J Allergy Clin Immunol (2005) 116(1):133-9. doi:10.1016/j.jaci.2005. 04.022

66. Tranter DC, Wobbema AT, Norlien K, Dorschner DF. Indoor allergens in Minnesota schools and child care centers. JOccup Environ Hyg (2009) 6(9):582-91. doi:10.1080/15459620903103454

67. Cai G-H, Mälarstig B, Kumlin A, Johansson I, Janson C, Norbäck D. Fungal DNA and petallergen levels in Swedish day care centers and associations with building characteristics. J Environ Monit (2011) 13(7):2018. doi:10.1039/c0em00553c

68. Permaul P, Hoffman E, Fu C, Sheehan W, Baxi S, Gaffin J, et al. Allergens in urban schools and homes of children with asthma. Pediatr Allergy Immunol (2012) 23(6):543-9. doi:10.1111/j.1399-3038.2012.01327.x

69. Custovic A, Fletcher A, Pickering CA, Francis HC, Green R, Smith A, et al. Domestic allergens in public places III: house dust mite, cat, dog and cockroach allergens in British hospitals. Clin Exp Allergy (1998) 28(1):53-9. doi:10.1046/j.1365-2222.1998.00183.x

70. Partti-Pellinen K, Marttila O, Mäkinen-Kiljunen S, Haahtela T. Occurrence of dog, cat, and mite allergens in public transport vehicles. Allergy (2000) 55(1):65-8. doi:10.1034/j.1398-9995.2000.00226.x

71. Macher JM, Tsai FC, Burton LE, Liu KS. Concentrations of cat and dustmite allergens in dust samples from 92 large US office buildings from the BASE Study. Indoor Air (2005) 15(Suppl 9):82-8. doi:10.1111/j.1600-0668. 2005.00347.x

72. Samadi S, Heederik DJJ, Krop EJM, Jamshidifard A-R, Willemse T, Wouters IM. Allergen and endotoxin exposure in a companion animal hospital. Occup Environ Med (2010) 67(7):486-92. doi:10.1136/oem.2009.051342

73. Nicholas C, Wegienka G, Havstad S, Zoratti E, Ownby D, Johnson CC. Dog characteristics and allergen levels in the home. Ann Allergy Asthma Immunol (2010) 105(3):228-33. doi:10.1016/j.anai.2010.06.019

74. Custovic A, Green R, Taggart SC, Smith A, Pickering CA, Chapman MD, et al. Domestic allergens in public places. II: dog (Can f1) and cockroach (Bla g 2) allergens in dust and mite, cat, dog and cockroach allergens in the air in public buildings. Clin Exp Allergy (1996) 26(11):1246-52. doi:10.1111/j.1365-2222. 1996.tb00521.x

75. Wardzynska A, Majkowska-Wojciechowska B, Pełka J, Korzon L, Kaczała M, Jarzebska M, et al. Association of house dust allergen concentrations with residential conditions in city and in rural houses. World Allergy Organ J (2012) 5(2):22-7. doi:10.1097/WOX.0b013e3182447fa8

76. Jeal H, Jones M. Allergy to rodents: an update. Clin Exp Allergy (2010) 40(11):1593-601. doi:10.1111/j.1365-2222.2010.03609.x

77. Gautrin D, Ghezzo H, Infante-Rivard C, Malo JL. Incidence and determinants of IgE-mediated sensitization in apprentices. A prospective study. Am J Respir Crit Care Med (2000) 162(4 Pt 1):1222-8. doi:10.1164/ajrccm.162.4.2001023

78. Krakowiak A, Szulc B, Górski P. Allergy to laboratory animals in children of parents occupationally exposed to mice, rats and hamsters. Eur Respir J (1999) 14(2):352-6. doi:10.1183/09031936.99.14235299

79. Matsui EC. Role of mouse allergens in allergic disease. Curr Allergy Asthma Rep (2009) 9(5):370-5. doi:10.1007/s11882-009-0054-x

80. Perry T, Matsui E, Merriman B, Duong T, Eggleston P. The prevalence of rat allergen in inner-city homes and its relationship to sensitization and asthma morbidity. J Allergy Clin Immunol (2003) 112(2):346-52. doi:10.1067/mai. 2003.1640
81. Liccardi G, Salzillo A, Sofia M, Piccolo A, Dente B, Russo M, et al. Sensitization to rodents (mouse/rat) in an urban atopic population without occupational exposure living in Naples, Italy. Eur Ann Allergy Clin Immunol (2012) 44(5):200-4.

82. Lorusso JR, Moffat S, Ohman JL. Immunologic and biochemical properties of the major mouse urinary allergen (Mus m 1). J Allergy Clin Immunol (1986) 78(5 Pt 1):928-37. doi:10.1016/0091-6749(86)90242-3

83. Cavaggioni A, Mucignat-Caretta C. Major urinary proteins, alpha(2U)globulins and aphrodisin. Biochim Biophys Acta (2000) 1482(1-2):218-28. doi:10.1016/S0167-4838(00)00149-7

84. Ohman JL, Hagberg K, MacDonald MR, Jones RR, Paigen BJ, Kacergis JB. Distribution of airborne mouse allergen in a major mouse breeding facility. JAllergy Clin Immunol (1994) 94(5):810-7. doi:10.1016/0091-6749(94) 90147-3

85. Hollander A, van Run P, Spithoven J, Heederik D, Doekes G. Exposure of laboratory animal workers to airborne rat and mouse urinary allergens. Clin Exp Allergy (1997) 27(6):617-26. doi:10.1046/j.1365-2222.1997.d01-548.x

86. Renström A, Bjoring G, Hoglund AU. Evaluation of individually ventilated cage systems for laboratory rodents: occupational health aspects. Lab Anim (2001) 35(1):42-50. doi:10.1258/0023677011911363

87. Curtin-Brosnan J, Paigen B, Hagberg KA, Langley S, O’Neil EA, Krevans M, et al. Occupational mouse allergen exposure among non-mouse handlers. J Occup Environ Hyg (2010) 7(12):726-34. doi:10.1080/15459624.2010.530906

88. Thulin H, Björkdahl M, Karlsson A-S, Renström A. Reduction of exposure to laboratory animal allergens in a research laboratory. Ann Occup Hyg (2002) 46(1):61-8. doi:10.1093/annhyg/mef022

89. Phipatanakul W, Eggleston PA, Wright EC, Wood RA. Mouse allergen. I. The prevalence of mouse allergen in inner-city homes. J Allergy Clin Immunol (2000) 106(6):1070-4. doi:10.1067/mai.2000.110796

90. Matsui EC, Wood RA, Rand C, Kanchanaraksa S, Swartz L, Eggleston PA. Mouse allergen exposure and mouse skin test sensitivity in suburban, middleclass children with asthma. J Allergy Clin Immunol (2004) 113(5):910-5. doi:10.1016/j.jaci.2004.02.034

91. Chew GL, Correa JC, Perzanowski MS. Mouse and cockroach allergens in the dust and air in northeastern United States inner-city public high schools. Indoor Air (2005) 15(4):228-34. doi:10.1111/j.1600-0668.2005.00363.x

92. Sheehan WJ, Rangsithienchai PA, Muilenberg ML, Rogers CA, Lane JP, Ghaemghami J, et al. Mouse allergens in urban elementary schools and homes of children with asthma. Ann Allergy Asthma Immunol (2009) 102(2):125-30. doi:10.1016/S1081-1206(10)60242-6

93. Bayard C, Holmquist L, Vesterberg O. Purification and identification of allergenic alpha $(2 \mathrm{u})$-globulin species of rat urine. Biochim Biophys Acta (1996) 1290(2):129-34. doi:10.1016/0304-4165(96)00006-2

94. Gordon S, Tee RD, Lowson D, Wallace J, Newman Taylor AJ. Reduction of airborne allergenic urinary proteins from laboratory rats. Br J Ind Med (1992) 49(6):416-22.

95. Renström A, Larsson PH, Malmberg P, Bayard C. A new amplified monoclonal rat allergen assay used for evaluation of ventilation improvements in animal rooms. J Allergy Clin Immunol (1997) 100(5):649-55. doi:10.1016/S00916749(97)70169-6

96. Lieutier-Colas F, Meyer P, Larsson P, Malmberg P, Frossard N, Pauli G, et al. Difference in exposure to airborne major rat allergen (Rat n 1) and to endotoxin in rat quarters according to tasks. Clin Exp Allergy (2001) 31(9):1449-56. doi:10.1046/j.1365-2222.2001.01180.x

97. Renström A, Karlsson AS, Tovey E. Nasal air sampling used for the assessment of occupational allergen exposure and the efficacy of respiratory protection. Clin Exp Allergy (2002) 32(12):1769-75. doi:10.1046/j.1365-2222.2002.01545.x

98. Arseneau AM, Hrabak TM, Waibel KH. Inhalant horse allergens and allergies: a review of the literature. Mil Med (2012) 177(7):877-82. doi:10.7205/ MILMED-D-12-00038

99. Roberts G, Lack G. Horse allergy in children. BMJ (2000) 321(7256):286-7. doi:10.1136/bmj.321.7256.286

100. Liccardi G, Dente B, Senna G, Martino M, de D, Amato L, et al. Sensitization to horse allergens without apparent exposure to horse. Report of two cases. Eur Ann Allergy Clin Immunol (2005) 37(9):350-2.

101. Novembre E, Mori F, Barni S, Pucci N, Rossi ME. Should the skin prick test to horse be included in the standard panel for the diagnosis of respiratory allergy? J Investig Allergol Clin Immunol (2009) 19(3):247-9. 
102. Liccardi G, D’Amato G, Antonicelli L, Berra A, Billeri L, Canonica G, et al. Sensitization to horse allergens in Italy: a multicentre study in urban atopic subjects without occupational exposure. Int Arch Allergy Immunol (2011) 155(4):412-7. doi:10.1159/000321414

103. Dandeu JP, Rabillon J, Divanovic A, Carmi-Leroy A, David B. Hydrophobic interaction chromatography for isolation and purification of Equ.cl, the horse major allergen. JChromatogr (1993) 621(1):23-31. doi:10.1016/0378-4347(93) 80072-C

104. Gregoire C, Rosinski-Chupin I, Rabillon J, Alzari PM, David B, Dandeu JP. cDNA cloning and sequencing reveal the major horse allergen Equ cl to be a glycoprotein member of the lipocalin superfamily. J Biol Chem (1996) 271(51):32951-9. doi:10.1074/jbc.271.51.32951

105. Goubran Botros H, Poncet P, Rabillon J, Fontaine T, Laval JM, David B. Biochemical characterization and surfactant properties of horse allergens. Eur J Biochem (2001) 268(10):3126-36. doi:10.1046/j.1432-1327.2001.02217.x

106. Felix K, Ferrándiz R, Einarsson R, Dreborg S. Allergens of horse dander: comparison among breeds and individual animals by immunoblotting. J Allergy Clin Immunol (1996) 98(1):169-71. doi:10.1016/S0091-6749(96)70239-7

107. Emenius G, Larsson PH, Wickman M, Härfast B. Dispersion of horse allergen in the ambient air, detected with sandwich ELISA. Allergy (2001) 56(8):771-4. doi:10.1034/j.1398-9995.2001.056008771.x

108. Elfman L, Brannstrom J, Smedje G. Detection of horse allergen around a stable. Int Arch Allergy Immunol (2008) 145(4):269-76. doi:10.1159/000110885

109. Emenius G, Merritt A-S, Härfast B. Dispersion of horse allergen from stables and areas with horses into homes. Int Arch Allergy Immunol (2009) 150(4):335-42. doi:10.1159/000226234

110. Kim JL, Elfman L, Mi Y, Johansson M, Smedje G, Norbäck D. Current asthma and respiratory symptoms among pupils in relation to dietary factors and allergens in the school environment. Indoor Air (2005) 15(3):170-82. doi:10.1111/j.1600-0668.2005.00334.x

111. Kim JL, Elfman L, Norbäck D. Respiratory symptoms, asthma and allergen levels in schools? Comparison between Korea and Sweden. Indoor Air (2007) 17(2):122-9. doi:10.1111/j.1600-0668.2006.00460.x

112. Zhao ZH, Elfman L, Wang ZH, Zhang Z, Norbäck D. A comparative study of asthma, pollen, cat and dog allergy among pupils and allergen levels in schools in Taiyuan city, China, and Uppsala, Sweden. Indoor Air (2006) 16(6):404-13. doi:10.1111/j.1600-0668.2006.00433.x

113. Merritt A-S, Emenius G, Elfman L, Smedje G. Measurement of horse allergen (Equ cx) in schools. ISRN Allergy (2011) 2011(1):1-6. doi:10.5402/2011/ 574258

114. Terho EO, Husman K, Vohlonen I, Rautalahti M, Tukiainen H. Allergy to storage mites or cow dander as a cause of rhinitis among Finnish dairy farmers. Allergy (1985) 40(1):23-6. doi:10.1111/j.1398-9995.1985.tb04150.x

115. Rautalahti M, Terho EO, Vohlonen I, Husman K. Atopic sensitization of dairy farmers to work-related and common allergens. Eur J Respir Dis Suppl (1987) 152:155-64.

116. Kronqvist M, Johansson E, Pershagen G, Johansson SG, van Hage-Hamsten M. Increasing prevalence of asthma over 12 years among dairy farmers on Gotland, Sweden: storage mites remain dominant allergens. Clin Exp Allergy (1999) 29(1):35-41. doi:10.1046/j.1365-2222.1999.00452.x

117. Heutelbeck ARR, Janicke N, Hilgers R, Kütting B, Drexler H, Hallier E, et al. German cattle allergy study (CAS): public health relevance of cattle-allergic farmers. Int Arch Occup Environ Health (2007) 81(2):201-8. doi:10.1007/ s00420-007-0207-y

118. Koskela HO, Happonen KK, Remes ST, Pekkanen J. Effect of farming environment on sensitisation to allergens continues after childhood. Occup Environ Med (2005) 62(9):607-11. doi:10.1136/oem.2004.014852

119. Remes ST, Koskela HO, Iivanainen K, Pekkanen J. Allergen-specific sensitization in asthma and allergic diseases in children: the study on farmers' and nonfarmers' children. Clin Exp Allergy (2005) 35(2):160-6. doi:10.1111/j.13652222.2005.02172.x

120. Prahl P. Allergens in cow hair and dander. Origin of cow allergens in the environment. Allergy (1981) 36(8):561-71. doi:10.1111/j.1398-9995.1981. tb01874.x

121. Ylönen J, Mäntyjärvi R, Taivainen A, Virtanen T. Comparison of the antigenic and allergenic properties of three types of bovine epithelial material. Int Arch Allergy Immunol (1992) 99(1):112-7. doi:10.1159/000236343
122. Mäntyjärvi R, Parkkinen S, Rytkönen M, Pentikäinen J, Pelkonen J, Rautiainen J, et al. Complementary DNA cloning of the predominant allergen of bovine dander: a new member in the lipocalin family. J Allergy Clin Immunol (1996) 97(6):1297-303. doi:10.1016/S0091-6749(96)70198-7

123. Rautiainen J, Auriola S, Konttinen A, Virtanen T, Rytkönen-Nissinen M, Zeiler T, et al. Two new variants of the lipocalin allergen Bos d 2 . J Chromatogr B Biomed Sci Appl (2001) 763(1-2):91-8. doi:10.1016/S03784347(01)00369-3

124. Rautiainen J, Rytkönen M, Syrjänen K, Pentikäinen J, Zeiler T, Virtanen T, et al. Tissue localization of bovine dander allergen Bos d 2. J Allergy Clin Immunol (1998) 101(3):349-53. doi:10.1016/S0091-6749(98)70247-7

125. Restani P, Ballabio C, Di Lorenzo C, Tripodi S, Fiocchi A. Molecular aspects of milk allergens and their role in clinical events. Anal Bioanal Chem (2009) 395(1):47-56. doi:10.1007/s00216-009-2909-3

126. Virtanen T, Louhelainen K, Mäntyjärvi R. Enzyme-linked immunosorbent assay (ELISA) inhibition method to estimate the level of airborne bovine epidermal antigen in cowsheds. Int Arch Allergy Appl Immunol (1986) 81(3):253-7. doi: $10.1159 / 000234143$

127. Hinze S, Bergmann KC, Løwenstein H, Hansen GN. Cow hair allergen (Bos d 2) content in house dust: correlation with sensitization in farmers with cow hair asthma. Int Arch Allergy Immunol (1997) 112(3):231-7. doi:10.1159/000237459

128. Zahradnik E, Sander I, Bruckmaier L, Flagge A, Fleischer C, Schierl R, et al. Development of a sandwich ELISA to measure exposure to occupational cow hair allergens. Int Arch Allergy Immunol (2011) 155(3):225-33. doi:10.1159/000319839

129. Ylönen J, Virtanen T, Rytkönen M, Mäntyjärvi R. Quantification of a major bovine allergen by a two-site immunometric assay based on monoclonal antibodies. Allergy (1994) 49(9):707-12. doi:10.1111/j.1398-9995.1994.tb02091.x

130. Virtanen T, Vilhunen P, Husman K, Happonen P, Mäntyjärvi R. Level of airborne bovine epithelial antigen in Finnish cowsheds. Int Arch Occup Environ Health (1988) 60(5):355-60. doi:10.1007/BF00405670

131. Berger I, Schierl R, Ochmann U, Egger U, Scharrer E, Nowak D. Concentrations of dust, allergens and endotoxin in stables, living rooms and mattresses from cattle farmers in southern Bavaria. Ann Agric Environ Med (2005) 12(1): $101-7$.

132. Williams DL, Breysse PN, McCormack MC, Diette GB, McKenzie S, Geyh AS. Airborne cow allergen, ammonia and particulate matter at homes vary with distance to industrial scale dairy operations: an exposure assessment. Environ Health (2011) 10(1):72. doi:10.1186/1476-069X-10-72

133. Virtanen T, Eskelinen T, Husman K, Mäntyjärvi R. Long- and short-term variability of airborne bovine epithelial antigen concentrations in cowsheds. Int Arch Allergy Immunol (1992) 98(3):252-5. doi:10.1159/000236193

134. Zahradnik E, Sander I, Brüning T, Chapman M, Raulf-Heimsoth M. Quantification of bovine allergens in different dust and food samples - comparison of polyclonal and monoclonal antibody-based ELISAs. The EAACIWAO World Allergy and Asthma Congress 2013. Milan: (2013). Available from: http://www.sessionplan.com/EAACI-WAO2013/

Conflict of Interest Statement: The authors declare that the research was conducted in the absence of any commercial or financial relationships that could be construed as a potential conflict of interest.

Received: 08 November 2013; accepted: 12 February 2014; published online: 03 March 2014.

Citation: Zahradnik E and Raulf M (2014) Animal allergens and their presence in the environment. Front. Immunol. 5:76. doi: 10.3389/fimmu.2014.00076

This article was submitted to Immunotherapies and Vaccines, a section of the journal Frontiers in Immunology.

Copyright (c) 2014 Zahradnik and Raulf. This is an open-access article distributed under the terms of the Creative Commons Attribution License (CC BY). The use, distribution or reproduction in other forums is permitted, provided the original author $(s)$ or licensor are credited and that the original publication in this journal is cited, in accordance with accepted academic practice. No use, distribution or reproduction is permitted which does not comply with these terms. 